\title{
LA QUIEBRA DEL SISTEMA HISPANO-GENOVÉS (1627-1700) ${ }^{1}$
}

por

\section{MANUEL HERRERO SÁNCHEZ}

Universidad Pablo de Olavide de Sevilla

RESUMEN: En este artículo se abordan los cambios efectuados en la relación entre la Monarquía Hispánica y Génova a partir de la invasión franco-saboyana de 1625 y hasta la muerte de Carlos II. La crisis de la simbiosis hispano-genovesa permite profundizar sobre el papel central jugado por las repúblicas mercantiles en una Europa predominantemente dinástica y ofrece una nueva perspectiva sobre las transformaciones internas experimentadas por ambos aliados y sobre el alcance de su desplazamiento en la escena internacional después de la paz de Westfalia. El fracaso de los programas autonomistas y de reactivación naval propugnados desde 1630 por los llamados republiquistas y la crisis provocada por el embargo de bienes genoveses en los territorios italianos de la corona en 1654 abrieron paso a un nuevo acercamiento destinado a frenar la política expansionista de Luis XIV, cuyos desalentadores resultados eran la prueba de la quiebra de un sistema de poder que habia logrado imponer su begemonía en Europa desde principios del siglo XVI.

Palabras ClaVe: Génova. Monarquía Hispánica. Republicanismo. Neutralidad. Crisis del siglo XVII. Guerra. Embargo. Facciones. Oligarquía. Relaciones internacionales.

ABSTRACT: This article examines the changes effected in the relationship between the Spanish Monarchy and Genoa from the Savoyard-French invasion in 1625 until the death of Charles II. The crisis of the Spanish-Genoese interdependence makes it possible to explore more deeply the central role of mercantile republics in a Europe where dynasties prevailed, and casts new light on the internal transformation experienced

${ }^{1}$ La presente contribución es fruto del trabajo relacionado con mi proyecto de investigación Dos repúblicas en un mundo de dinastías: las Provincias Unidas, Génova y la Monarquia Hispánica. Siglo XVI-XVII financiado por el Ministerio de Educación y Ciencia en el marco del programa Ramón y Cajal. Muchas de las reflexiones aquí incluidas parten asimismo del contraste de opiniones con el resto de los miembros del equipo de investigación dirigido por Bartolomé Yun Casalilla que, bajo el título Elites para un Imperio, 1492-1713, cuenta con la financiación de la Fundación Carolina (CEH9/02). 


\begin{abstract}
by both allies, as well as on their decline on the international scene after the Peace of Westphalia. The failure of both neutrality programmes and naval reactivation advocated by the repubblichisti since the 1630s, together with the crisis brought about by the seizure of Genoese goods in the Italian territories of the Crown in 1654, paved the way for a new approach. This aimed at hampering the expansionist policy of Louis XIV, whose discouraging success provided evidence of a power system that was breaking down after having predominating in Europe since the beginning of the sixteenth century.
\end{abstract}

KEY WORDS: Genoa. Spanish Monarchy. Republicanism. Neutrality. Seventeenth-century crisis. War. Seizure. Factions. Oligarchy. International relations.

\title{
I. LA CRISIS DE UN MODELO
}

A principios de 1648, en pleno esfuerzo por sofocar el levantamiento del reino de Nápoles y ante la creciente presión francesa en el Mediterráneo que había culminado dos años antes con la toma de Porto Longone y Piombino, el embajador del monarca Católico en Génova, Antonio Ronquillo y Briceño, mostraba su preocupación por el hecho de que incluso aquellos sectores más afines a los intereses españoles en el gobierno de la república parecían «insinuar que las armas de Vuestra Majestad no están ya en estado de defenderlos»². En una enérgica respuesta a tales preocupaciones, que no hicieron sino crecer ante el auge de la piratería francesa en las costas de la Liguria, el Consejo de Estado en Madrid reafirmaba el compromiso adquirido por la Monarquía desde la firma del acuerdo de condotta entre Carlos V y Andrea Doria en 1528 en defensa de la conservación y la libertad de la república. Función protectora que no era desinteresada y que, como se indicaba en la misma consulta, derivaba asimismo de la importancia que para el sistema imperial hispánico tenía el mantenimiento en su órbita de uno de los principales enclaves estratégicos sin el que «quedaría en riesgo lo demás de Vuestra Majestad en Italia» ${ }^{3}$. Las dificultades de la corona para poner coto al desafío de Francia se podrían traducir en un cambio de alianzas por parte de una república que, según señalaba en su voto particular el marqués de Velada, «siempre hará más por la corona a quien más temiese» ${ }^{4}$.

El diagnóstico de Velada sobre la inconsistencia y la volatilidad de los acuerdos alcanzados con los regímenes republicanos, que no parecían regirse más que por el interés particular y no se detenían en cuestiones de honor, respondía a los clásicos prejuicios contra dicho modelo de gobierno pero dejaba de lado los múltiples factores de interdependencia que vinculaban a la república de Génova con

2 Archivo General de Simancas (AGS), Estado, leg. 3603, Carta de Ronquillo sobre la posición de los miembros del Conselleto ante las amenazas de Francia, Génova, 17-3-164

3 AGS, Estado, leg. 3603, Consulta del Consejo de Estado, Madrid, 9-7-1648.

${ }^{4}$ Ibid.

Hispania, LXV/1, núm. 219 (2005) 115-152 
la Monarquía Hispánica. Una perfecta simbiosis en la que uno de los socios se encargaba de velar por la defensa militar del conjunto y brindar nuevas posibilidades de promoción para sus respectivas elites, mientras el otro ofrecía los necesarios recursos financieros y logísticos únicos capaces de asegurar la expansión y consolidación del sistema imperial de los Habsburgo's.

El inusitado grado de estabilidad social experimentado por el agregado hispano-genovés y su indiscutible superioridad, tanto en los campos de batalla como en los mercados de capitales hasta bien entrado el siglo XVII, ponían de manifiesto los beneficios derivados de dicha colaboración y aparecen como una prueba palpable del papel determinante jugado por las repúblicas mercantiles en una Europa sobre la que se ha enfatizado en exceso el protagonismo ejercido por la Corte y la gracia del príncipe ${ }^{6}$. Es indudable que los banqueros genoveses y los miembros más conspicuos de su refinada aristocracia gozaron de los favores del patronazgo regio y llegaron incluso a alcanzar cargos de primer orden en el gobierno o en la dirección de sus ejércitos y armadas. Pero como contrapartida, y según apuntaba Campanella en 1636, la república era «la unión, el busto y la sangre de este cuerpo» no sólo por la liquidez y el crédito con los que sus hombres de negocios financiaban las costosas operaciones militares de la Monarquía sino también por la cohesión que sus abigarradas redes mercantiles asentadas en territorios tan distantes como Nápoles, Castilla, Sicilia, Milán, Valencia o los Países Bajos, otorgaban al conjunto del sistema ${ }^{7}$. Los

5 La necesidad de profundizar en el estudio de las relaciones de Génova con el sistema imperial hispánico, como un método adecuado para analizar las transformaciones internas experimentadas por la república la puso de relieve PACINI, A.: «La repubblica di Genova vista da Simancas» Società e storia, 67, (1995), pp. 141-154. Dicho esfuerzo se observa en su minusioso trabajo sobre la naturaleza del acuerdo de 1528, PACINI, A.: I presuposti politici del 'secolo dei Genovesi': la Riforma del 1528, Génova, 1990 y, del mismo autor, La Genova di Andrea Doria nell'Impero di Carlo V, Florencia, 1999. Por nuestra parte acabamos de publicar un estudio sobre las características del entramado hispano-genovés, HERrERo SÁNCHEZ, M.: "Génova y el sistema imperial hispánico» en ÁlvarezOssorio, A. y García García, B. (eds.), La Monarquía de las Naciones. Patria, nación y naturaleza en la Monarquía de España, Madrid, 2004, pp. 528-562.

${ }^{6}$ Un primer balance sobre esta cuestión lo tenemos en Herrero SÁNCHEZ, M.: «Las repúblicas mercantiles, ¿Alternativa al modelo dinástico? Génova, las Provincias Unidas y la Monarquía Hispánica en la segunda mitad del siglo XVII», en Crespo, A. y Herrero, M. (eds.), España y las 17 Provincias de los Países Bajos. Una revisión historiográfica (siglos XVI-XVIII), Córdoba, 2002, 1 Vol., pp. 189-227. Al respecto, el trabajo de Yves Durand, aunque deja de lado el caso genovés para centrarse en los modelos veneciano y holandés, sigue siendo un referente fundamental, DURAND, Y.: Les Républiques au temps des Monarchies, París, 1973.

7 No en vano, en este mismo opúsculo, Campanella pronosticaba el desplazamiento de la Monarquía Católica por parte de Francia en cuanto Génova abandonase su subordinación a los Austrias: «El imperio austriaco español ha de desaparecer pronto en la desunión del mismo en los muchos miembros muy alejados entre sí y que no se pueden ayudar unos a otros si no es por medio de la navegación muy dificultosa, o por medio de otros principados intermedios confederados como Génova, que tiene unidos a Nápoles, Milán y España, y la Valtelina, que tiene unidos el Estado de Flandes y el Imperio con el Estado de Milán e Italia. Deshechos estos vínculos caerá todo el cuerpo 
genoveses compraron feudos y emparentaron con las principales familias de la nobleza española e italiana en un proceso de integración en el seno de una aristocracia de marcado talante internacional de la que llegaron a constituirse en uno de sus mejores prototipos. Y ello porque, gracias a su alta tasa de movilidad y al mantenimiento de sus actividades financieras y mercantiles, lograron introducir nuevas formas de gestión del patrimonio nobiliario y ayudaron a difundir una serie de valores y de pautas de comportamiento que dotaron de cierta homogeneidad al conjunto de estos territorios y dieron como resultado un modelo cultural híbrido capaz de imponerse en el resto de Europa hasta finales del siglo XVII cuando sería desplazado por las pautas estéticas procedentes de Francia ${ }^{8}$.

La importancia crucial ejercida por Génova para el buen funcionamiento del complejo entramado estratégico de la Monarquía Hispánica, «llave.y puerta de Italia» y «ojo derecho del imperio» como solían repetir los contemporáneos, quedó escenificada en el grandioso programa iconográfico diseñado para decorar el salón de Reinos del Palacio del Buen Retiro donde el socorro de Génova por parte de las tropas del marqués de Santa Cruz se encontraba situado en igualdad de condiciones con victorias tan decisivas como la toma de Breda, la recuperación de Bahía o la defensa de Cádiz. A pesar del malestar que había supuesto en la república la apropiación del enclave costero de Finale por parte española en $1598^{\circ}$, el papel decisivo jugado por los efectivos militares de la Monarquía para obligar al duque de Saboya a retirarse de las plazas genovesas conquistadas con el beneplácito de Francia durante el famoso annus mirabilis de 1625 era la prueba

de esta monarquía...Y ciertamente España no puede mantenerse sin Génova...Cuando Génova abriese los ojos y conociese que la conservación de la potencia y sostenimiento de esta monarquía depende de ella, y no la suya de España, recuperaría cuanto tiene España de. Génova y lo llevaría a mejor parte.» Campanella, T.: La Monarquía de las Naciones, en la edición de Primitivo Mariño Gómez para el Centro de Estudios Constitucionales, Madrid, 1989, pp. 201-204.

8 Las mutuas influencias artísticas y culturales entre Génova y España han sido abordadas recientemente por un conjunto de autores en BOCCARDO, P., COLOMER, J.L. y Di FABIO, C. (Eds.): Genova e Spagna. Opere, artisti, comittenti, collezionisti, Milán, 2002.

9 Sobre el marquesado de Finale véase EdelmaYer, F., «Il Sacro Romano Impero nel Cinquecento ed i piccoli feudi italiani: l'essempio del marchesato finalese» en Atti dei convegni internazionali sulla storia del Finale. La Spagna, Milano ed il Finale: il ruolo del marchesato tra medioevo ed età moderna, Finale, 1994, pp. 43-61. La Monarquía había ocupado militarmente el pequeño enclave marítimo de Finale en 1572 para evitar una eventual anexión del mismo por parte de Francia. En 1598, Madrid tomaría formalmente posesión del marquesado a pesar de las vanas protestas genovesas ante los deseos de la Corona y de sus delegados en Milán de consolidar su presencia en la costa ligur mediante nuevas adquisiciones territoriales. A las maniobras del conde de Fuentes por las que, en 1605, reivindicaba antiguos derechos milaneses en la Lunigiana y en el golfo de la Spezia -que fueron desestimadas desde Madrid- siguió la introducción de tropas españolas en el feudo de Sassello en 1611 con la excusa de evitar una posible ocupación del mismo por parte del duque de Mantua. La reacción anti-española que se desató en la república con escritos que, como los de Alessandro Cattaneo o Gio Francesco Spinola, exigían una revisión de la alianza con la Monarquía, ha sido analizada por Costantini, C.: La Repubblica di Genova nell' età moderna, Turín, 1978, pp. 223-225.

Hispania, LXV/1, núm. 219 (2005) 115-152 
más elocuente de la seriedad con la que, desde Madrid, se ejercía su función de defensora de la libertad de la república ${ }^{10}$.

A esta función protectora se sumaba el papel estabilizador que el pacto con la Monarquía Hispánica había aportado a la turbulenta política interior genovesa. Durante los dramáticos acontecimientos de 1528, y de nuevo en 1575-1576, la mediación española actuó como un factor de primer orden para cercenar los sangrantes conflictos de facciones que habían devastado la república con anterioridad y que habían propiciado la constante injerencia extranjera en sus asuntos internos. La contrapartida era una cierta sumisión a las decisiones adoptadas desde Madrid, lo que no dejaba de ser criticado por aquellos sectores que aspiraban a alcanzar unas cuotas de autonomía semejantes a las que disfrutaba la república de Venecia. No obstante, dicha limitación parecía quedar contrarrestada por las amplias posibilidades de promoción comercial y financiera derivadas de la posición privilegiada de la que gozaban los genoveses en los mercados de la Monarquía ${ }^{11}$.

Aunque pueda resultar paradójico, sería precisamente a partir de 1625 cuando se experimentaron las primeras señales de agotamiento en una colaboración que tan buenos resultados había ofrecido hasta el momento ${ }^{12}$. A pesar de la contundente respuesta española, el ataque de Saboya venía a demostrar que la república había acabado por convertirse en uno de los objetivos más vulnerables de los múltiples enemigos de la Monarquía Hispánica y que su posición de aparente neutralidad quedaba puesta en duda por todos aquellos que pretendían limitar las

${ }^{10}$ El ataque contra Génova era el resultado de la alianza anti-española suscrita entre Francia, Saboya y Venecia el año anterior para hacer frente a la espinosa cuestión de la Valtelina que, en el caso de la república, se complicaba por una serie de conflictos bilaterales con Carlos Manuel I de Saboya por la posesión del feudo de Zuccarello. Como señala Bitossi, la movilización militar adoptó un tono patriótico y religioso como consecuencia de los pillajes ejecutados por la tropas protestantes presentes en el ejército enemigo. Aún así, la defensa de la república fue, sobre todo, el resultado del imponente apoyo militar prestado por España que había sido movilizado, en gran medida, gracias a la decidida acción de las colonias genovesas asentadas en los territorios de la Italia española. A las acciones promovidas por el virrey de Sicilia, el cardenal Gianettino Doria, o por el duque de Tursi, comandante de las galeras de España, se sumaron los subsidios aportados desde Nápoles por figuras como el príncipe de Melfi o el marqués de Strevi, ambos de origen genovés o, desde Flandes, por el influyente Ambrogio Spinola. La entrada de tropas españolas en Génova iba acompañada de la apertura de un segundo frente en el Montferrato situación que permitió expulsar con facilidad a los invasores. Sobre estas cuestiones véase, BITOSSI, C.: «L'antico regime genovese, 1576-1797》 en Puncuh, D. (ed.), Storia di Genova. Mediterraneo, Europa, Atlantico, Génova, 2003, pp. 435-439.

11 Cuestiones que son tratadas con detenimiento en los artículos de Arturo Pacini y de Thomas Kirk en este monográfico.

12 Poco antes del bombardeo francés sobre Génova en 1684, el enviado francés señalaba que: «sólo se puede decir que la república ha gozado de una perfecta libertad después del año 1625 o quizá algunos años después» en AGS, Estado, leg. 3621, Consulta del consejo de Estado sobre un papel adjunto remitido por Juan Carlos Bazán del enviado francés, Saint-Olon, en el que informa sobre el estado y disposición de la república de Génova y de los medios de reducirla y sujetarla a Francia, Madrid, 16-12-1684. Existen varias copias de este mismo memorial: Biblioteca Nacional de Madrid (BNM), Mss. 11021, fols. 120-172 y Archivio Storico del Comune di Genova (ASCG), Fondo Brignole Sale, Mss. 109-E-12 BS. 
pretensiones hegemónicas de los Habsburgo. La necesidad de la Monarquía de mantener operativo el Camino Español hacia los Países Bajos mediante el control de los pasos alpinos obligó al gobernador de Milán a alcanzar, en 1628, un acuerdo de colaboración con el duque de Saboya con objeto de resolver de manera favorable la espinosa cuestión de la sucesión de Mantua-Montferrato y frenar, de este modo, el avance francés en el norte de Italia ${ }^{13}$. El fracaso de los sucesivos intentos por tomar Casale, que obligaron a divertir importantes contingentes desde los Países Bajos, y la escasa fiabilidad de la alianza con el duque de Saboya, que al año siguiente volvió a acercarse a París, supusieron un contundente golpe para la reputación militar española.

Uno de los efectos colaterales más perniciosos derivados de la desastrosa intervención en la guerra de Mantua fue el recelo que provocaron en Génova los acuerdos suscritos entre el gobernador de Milán, Gonzalo Fernández de Córdoba, y Turín, habida cuenta de las veleidades expansionistas del duque a costa de los territorios de la república ${ }^{14}$. La desconfianza hacia la Monarquía subió de tono debido a la actitud pasiva mostrada por Madrid ante el estallido, en 1628, de la conjura de Giulio Cesare Vacchero que, financiada e impulsada por Carlos Manuel I de Saboya, tenía por objeto provocar la caída del régimen aristocrático ${ }^{15}$.

\footnotetext{
13 La guerra por la sucesión de Mantua constituye uno de los principales episodios de la escalada militar entre Francia y la Monarquía Hispánica y ha sido abordada en el contexto del conflicto general que asolaba Europa durante esos años. Además de las precisas observaciones de Elliott, que no duda en definirla como «la más seria equivocación de la carrera política de Olivares», (ELLIOTT, J.H.: Richelieu y Olivares, Barcelona, 1984, p. 128) contamos con el análisis de STRADLING, R.A.: «Prelude to Disaster: The Precipitation of the War of the Mantuan Succession, 1627-1629", Historical Journal, 33, (1990), pp. 769-785 o con el reciente trabajo de PARroTt, D.: «The Mantuan Succession, 1627-1631: A Sovereignty Dispute in Early Modern Europe», The English Historical Review, 112, 445, (1997), pp. 20-65. Para los momentos previos al estallido del conflicto, y con una rica información sobre la guerra de 1625 entre Saboya, la Monarquía y Génova, véase, QUAZZA, R: Mantova e Montferrato nella politica europea alla vigilia della guerra per la successione (1624-1627), Mantua, 1922.

${ }^{14}$ Como observó con acierto Cano de Gardoqui, el resultado de la paz de Lyón de 1601, por la que Francia abandonaba el ducado de Saluzzo a cambio de la renuncia por parte de Saboya de unos territorios considerablemente más amplios del otro lado de los Alpes, lanzó al duque a una política de expansión territorial en Italia que convertiría a Génova en uno de sus objetivos favoritos, CaNO DE GARDOQUi, J.L.: La cuestión de Saluzzo (1588-1601), Valladolid, 1962, pp. 240-241. La república era consciente de que un acuerdo con Turín facilitaba a Madrid el envío de sus tropas a los Países Bajos por lo que recelaba de los perjuicios que tales negociaciones podrían acarrear para la integridad de su territorio. Temores que se desvanecieron gracias al tratado de Bossolino entre Francia y Saboya, en mayo de 1629, que junto al fracaso de la expedición de Ambrogio Spinola condujeron a la paz de Cherasco en 1631. El conflicto entre Saboya y Génova seguiría abierto como muestra la interesante relación efectuada por Melchor de Arce sobre «lo pasado en las cosas de Mantua y el Montferrato y las diferencias entre la república de Génova y Saboya», BNM, Mss. 11018, fol. 286289. La mediación española abrió finalmente paso al acuerdo de paz en 1634, BNM, Mss. 11.000 , Ajustamiento para la ejecución de las restituciones que, para los capítulos de la paz se deben hacer entre el duque de Saboya, Victor Amadeo I, y la república de Génova, fol. 206r.-207v.

15 Como apunta Franco Venturi en unas reveladoras páginas sobre las repúblicas mercantiles en la Edad Moderna, la conjura de Giulio Cesare Vachero tenía un fuerte componente populista y
}

Hispania, LXV/1, núm. 219 (2005) 115-152 
Postura que, criticada con dureza por influyentes figuras de marcado talante anti-español como Raffaele della Torre, fue considerada por gran parte de la nobleza genovesa como una prueba irrefutable del papel subsidiario que los intereses de la república parecían jugar en la nueva estrategia general de los Austrias madrileños. Más aún cuando, al año siguiente, el embajador español pareció hacerse eco de la solicitud de Vincenzo Ligalupo que pedía el apoyo del rey Católico, en calidad de garante de las Leges Novae de 1576, para forzar la entrada en el restringido grupo de la nobleza de determinadas familias populares según exigían las leyes de adscripción aprobadas en dicho acuerdo ${ }^{16}$. Como indica Bitossi, frente a posturas que, como las de Andrea Spinola, apostaban por una solución veneciana de cierre de hermético de la clase dirigente, a partir de 1628 , a las adscripciones ordinarias vinieron a sumarse, en los momentos de mayor necesidad económica, algunas inscripciones venales ${ }^{17}$. A pesar del gran número de libelos que acusaban a Madrid de alentar las protestas de los segmentos populares, no es probable que la Monarquía estuviese atenta a apoyar cualquier tipo de movimiento desestabilizador. $Y$ no sólo porque su interés radicase en un mantenimiento del régimen oligárquico para evitar toda posible intromisión foránea al amparo de las disensiones internas sino, asimismo, por el temor a un posible contagio en el ducado de Milán ante el progresivo descontento provocado por los negativos efectos de la guerra y agudizado por la propagación de la peste ${ }^{18}$.

\footnotetext{
democratizador y se inspiraba en una serie de opúsculos que habían sido redactados por Giovanni Ansaldo con títulos tan reveladores como Verità esaminata a favor del popolo il quale con ingiustitia è tenuto fuori del governo di Genova contro alcuni tiranni dell'istesso popolo che già se ne credono impossessati con fraude. VenTURI, F.: Utopie e riforma nell'illuminismo, Turín, 2001 ( $1^{\text {a }}$ ed. 1970), p. 39. Los intentos de mediación del embajador español, marqués de Castañeda, para evitar un aumento de la tensión entre Saboya y la república fueron desatendidos desde Génova que procedió al ajusticiamiento de los conjurados con el beneplácito del marqués de los Balbases, Ambrogio Spinola, que, como señala Bitossi, actuaba como un eficaz intermediario entre le república y el Conde Duque de Olivares. La conjura, a la que siguieron una serie de atentados contra determinadas autoridades, impulsó la creación, ese mismo año, de los Inquisidores de Estado que, a partir de entonces, se encargarían de desarticular nuevos complots y de poner en pie un adecuado sistema de espionaje, BITOSSI, C.: «L'antico regime genovese...cit.», pp. 439-440. Sobre esta nueva magistratura véase, CANOSA, R.: All'origine delle polizie politiche. Gli inquisitori di Stato a Venezia e a Genova, Milán, 1989, pp. 113-167.

16 Costantini, C.: La repubblica di Genova...cit., pp. 258-262.

17 No hay que olvidar que esta ampliación del grupo dirigente permitía consolidar, a la postre, la hegemonía de la nobleza al evitar la aparición de un grupo antagonista rico y descontento por su marginación. BITOSSI, C.: «Il tempo deli oligarchi. Note sulla storia politica genovese nella prima età moderna», Annali dell'Università di Ferrara. Sezione lettere, Nuova serie 4, (2003), pp. 139-140. Sobre estas cuestiones véase también, NiCORA, M.: «La nobiltà genovese dal 1528 al 1700», Miscellanea Storica Ligure, II, (1961), pp. 217-310. Según Durand, en los sistemas republicanos las personas con derechos políticos eran menos numerosas que en los monárquicos. En Génova, para mediados del siglo XVII, el grupo dirigente rondaba los 1000 efectivos. DURAND, Y.: Les républiques...cit., p. 200.

18 SignOROTTO, G.: "Stabilità politica e trame antispagnole nella Milano del Seicento» en Bercé, Y.M. y Fasano Guarini, E. (dir.), Complots et conjurations dans l'Europe Moderne, Roma, 1996, p. 728.
}

Hispania, LXV/1, núm. 219 (2005) 115-152 
La Monarquía no sólo se mostraba incapaz de frenar la creciente amenaza procedente del exterior ni la intervención de otras potencias en los asuntos internos de la república, como había hecho hasta el momento, sino que otro de los axiomas sobre los que reposaba el acuerdo hispano-genovés, los abultados beneficios financieros derivados de su monopolio sobre las finanzas de la Corona, se puso también en entredicho con la suspensión de pagos de 1627. La reanudación del conflicto con las Provincias Unidas a partir de 1621 y la activa participación española en la guerra de los 30 años supusieron un aumento disparatado de los gastos en un momento de contracción económica. Aunque la corona siguió contando con el flujo de capitales ofrecido por los banqueros genoveses, las dificultades por las que atravesaban las ferias cambiarias del norte de Italia y la preeminencia alcanzada por Ámsterdam como nuevo núcleo internacional de pagos animaron a Olivares a arbitrar los mecanismos necesarios para ampliar y diversificar el número de prestamistas. La bancarrota de 1627 no supuso, como tantas veces se ha repetido, el definitivo desplazamiento de los hombres de negocios genoveses y su sustitución por los de origen judeo-converso portugués ${ }^{19}$. Los trabajos de Carlos Álvarez Nogal y de Carmen Sanz Ayán en este mismo monográfico nos permiten observar que los banqueros de la república siguieron ocupando el lugar principal hasta la década de 1640 y, en muchos casos, colaboraron de forma activa con sus homólogos portugueses que, gracias a su amplia red de contactos, tenían mayores facilidades para realizar provisiones de fondos en los Países Bajos, escenario principal del esfuerzo militar de la corona. A pesar de esta diversificación y de un aparente aumento del número de prestamistas, la capacidad crediticia de la Monarquía descendió dramáticamente a lo largo de la crítica década de 1640 y, fracasados los intentos por volver a involucrar a los genoveses tradicionales tras la bancarrota de 1647, el desinterés de los mismos por las nuevas consignaciones y sus dificultades para operar de manera autónoma en las dinámicas plazas del norte de Europa pusieron de relieve las limitaciones de la república de Génova para cubrir con eficiencia su función de socio capitalista del conjunto. De modo especial cuando, debido al cierre del Camino Español tras la caída de Breisach en 1638, las partidas de plata remitidas por la ruta mediterránea vía Génova tan sólo servían para cubrir las necesidades de numerario en los territorios italianos de la Monarquía pero hacían muy difícil enviar las provisiones necesarias a Flandes donde, desde la entrada de Francia en la guerra en 1635, la Monarquía tenía abierto un doble frente militar. En un contexto semejante, y una vez resuelto el contencioso colonial en Brasil debido a la rebelión de Portugal, la paz con las Provincias Unidas aparecía como el camino más adecuado para recuperar el terreno perdido. En nuestro estudio sobre el proceso de acercamiento

19 Véanse las distintas interpretaciones que sobre el alcance de dicha bancarrota ofrecen en este volumen Thomas Kirk y Carlos Álvarez Nogal. La bibliografía sobre el siglo de los genoveses, es muy abundante. En un reciente balance realizado por Canosa se ofrece un completo elenco de las aportaciones de Ruiz Martín, Carande, Sanz Ayán, Álvarez Nogal, Neri, Doria, Muto, Otte o Kellebenz. CANOSA, R., Banchieri genovesi e sourani spagnoli tra Cinquecento e Seicento, Roma, 1998.

Hispania, LXV/1, núm. 219 (2005) 115-152 
hispano-neerlandés con posterioridad a 1648 hemos tenido ocasión de analizar la facilidad con la que los hombres de negocios holandeses se insertaron en los principales mercados de la Monarquía Hispánica amparados por numerosos privilegios aduaneros y por todo tipo de concesiones destinadas a convertirlos en los nuevos socios privilegiados de la corona ${ }^{20}$.

Ahora bien, la sustitución de la república de Génova por la república de las Provincias Unidas entrañaba una serie de modificaciones que evidenciaban el declive de la Monarquía Hispánica y las fuertes diferencias entre ambos modelos republicanos. Frente a lo que le ocurría al anterior socio mercantil genovés, las Provincias Unidas gozaban de una completa autonomía política, lo que les permitía ejercer un papel de arbitraje en los distintos contenciosos europeos y coloniales sin necesidad de someterse a los dictámenes procedentes de Madrid. La capacidad de la Compañia de las Indias Orientales para interiorizar los costes de protección en la defensa de sus propiedades ultramarinas y el componente gubernamental y territorial aportado por la Casa de Orange permitieron a la república salir airosa de los sucesivos desafíos efectuados, a lo largo de la segunda mitad del siglo XVII, por unas monarquías que no dudaron en acudir a la fuerza de las armas para desplazar de sus mercados a los intermediarios neerlandeses ${ }^{21}$. Para entonces, la corona española, lejos de poder aplicar programas de guerra económica como el puesto en marcha con relativo éxito entre 1621 y 1646 , sufría una creciente dependencia con respecto a los servicios navales y de aprovisionamiento que las Provincias Unidas parecían ofrecer con suma eficacia. A cambio, los comerciantes neerlandeses recibieron de Madrid tan amplias ventajas para operar sin trabas en sus mercados que hicieron disparar el contrabando y provocaron una sustancial disminución de los ingresos de la coro-

${ }^{20}$ Herrero SÁNCHEz, M.: El acercamiento bispano-neerlandés (1648-1678), Madrid, 2000. Situación de privilegio que fue en detrimento no sólo de los genoveses sino también de los comerciantes ingleses que habían gozado de una posición de primacía desde la firma de la paz de Londres en 1630 y que, en parte por las turbulencias derivadas de la guerra civil y en parte por la posición privilegiada de sus contrincantes neerlandeses, se vieron desplazados de los mercados hispanos. No en vano, los beneficios extraídos por las Provincias Unidas de la paz de Munster han sido considerados por Israel como uno de los principales detonantes del primer conflicto naval anglo-neerlandés a partir de 1652. IsRAEL, J.I.: «England's Mercantilist Response to Dutch World Trade Primacy, 1647-1674", S: Groenveld, M. Wintle (eds.), State and Trade. Government and the Economy in Britain and the Netherlands since the Middle Ages. Papers delivered to the Tenth Anglo-Dutch Historical Conference, Nijmegen, 1988, Zutphen, 1992, pp. 50-61.

${ }^{21}$ El recurso por parte de la república de las Provincias Unidas a uno de los principales resortes diplomáticos utilizados por los modelos dinásticos, la política matrimonial entre la casa Orange y la de Estuardo, permitió limitar las tensiones mercantiles entre ambas potencias marítimas y puso las bases de la futura alianza anglo-neerlandesa única capaz de oponerse con éxito a los intentos expansionistas de Luis XIV. ISRAEL, J.I.: "The Courts of the House of Orange c.1580-1795» en Adamson, J. (ed.), The Princely Courts of Europe, 1500-1750, Londres, 1999, pp. 119-139, IsRAEL, J.I. (ed.): The Anglo-Dutch Moment: Essays on the Glorious Revolution and its World Impact, Cambridge, 1991 o el trabajo de RowEN, H.H., The Princes of Orange: the stadbolders in the Dutch Republic, Cambridge, 1988.

Hispania, LXV/1, núm. 219 (2005) 115-152 
$\mathrm{na}^{22}$. Si a esto le sumamos que dichos hombres de negocios, salvo contadas excepciones y frente a lo ocurrido con los financieros genoveses, no parecían estar dispuestos a acudir con sus capitales a las necesidades crediticias de una monarquía en crisis, no es difícil de explicar la patente pérdida de capacidad militar del sistema imperial hispánico ${ }^{23}$. Su completo desinterés por la cada vez menos atractiva política de patronazgo regio y su limitada voluntad de integración con las elites locales, en especial si se compara con el intenso grado de inserción de los genoveses en el seno de la Monarquía, explican el escaso impacto que las pautas culturales y los modelos sociales procedentes de las Provincias Unidas ejercieron en aquellos territorios donde operaban sus comerciantes. La Monarquía Católica, que había asegurado con gran capacidad la protección de sus anteriores aliados genoveses, caía ahora en una posición de mera dependencia económica con respecto a sus nuevos socios mercantiles y se véía incluso obligada a solicitar el apoyo naval y militar de las Provincias Unidas. La compleja y bien trabada red de alianzas holandesa se convirtiría, así, en el factor clave para evitar la completa fragmentación de la Monarquía hasta el estallido de la guerra de Sucesión ${ }^{24}$.

La quiebra del agregado hispano-genovés y la entrada en acción de otros socios mercantiles, primero holandeses y posteriormente ingleses, no supuso, sin embargo, la ruptura definitiva de los lazos que unían a la Monarquía Católica con Génova como podría hacer pensar el absoluto vacío historiográfico en torno a las relaciones entre ambos aliados durante la segunda mitad del siglo XVII. Salvo las páginas dedicadas recientemente por Carlo Bitossi o algunas referencias puntuales realizadas por Domínguez Ortiz o por historiadores que como Signorotto o Álvarez-Ossorio se han ocupado del ducado de.Milán, carecemos de estudios de relieve al respecto ${ }^{25}$. Situación difícil de explicar si tene-

${ }^{22}$ Sobre estas cuestiones son fundamentales los ya clásicos trabajos de ALCALÁ-ZAMORA, J.: España, Flandes y el Mar del Norte, (1618-1639). La última ofensiva europea de los Austrias madrileños, Barcelona, 1975 (contamos con una reciente reedición, Madrid, 2001), que enfatiza las limitaciones de la guerra económica emprendida por la Corona. Perspectiva que ha sido puesta en cuestión por ISRAEL, J.I.: La república bolandesa y el mundo bispánico, 1606-1661, Madrid, 1997 ( $1^{\text {a }}$ ed. en inglés en 1982).

23 Los múltiples trabajos de Carmen Sanz sobre las actividades financieras de los hombres de negocios holandeses en la Monarquía Hispánica muestran que, lejos de actuar como meros prestamistas, sus intereses iban dirigidos al control de una serie de recursos que, como la lana o la sal, eran fundamentales para el buen funcionamiento de su emporio mercantil o que, como el asiento de esclavos, constituían una pieza clave para aumentar sus actividades fraudulentas en los mercados ibéricos y americanos. Las principales aportaciones al respecto han sido reunidas en una reciente recopilación en SANZ AYÁN, C.: Estado, monarquía y finanzas. Estudios de Historia financiera en tiempos de los Austrias, Madrid, 2004.

${ }^{24}$ Sobre estas cuestiones hemos realizado una serie de puntualizaciones en HERRERo SÁNCHEZ, M.: «Las Provincias Unidas y la Guerra de Sucesión española», Pedralbes, 22, (2002) pp. 133-153. Véase también ISRAEL, J.I.: Conflicts of Empires. Spain, the Low Countries and the Struggle for World Supremacy, 1585-1713, Londres, 1997.

${ }^{25}$ Si dejamos de lado los aspectos financieros que, como ya hemos indicado, se han tratado con mayor atención, el único que se ha acercado de modo sistemático al estudio de las relaciones hispa- 
mos en cuenta el rico y abundante material archivístico conservado, que constituye el mejor reflejo del interés que suscitaban los asuntos genoveses tanto en Madrid como entre sus delegados locales en Nápoles, Milán, Sicilia o en los Países Bajos y el detenido seguimiento con el que todos aquellos temas relativos a la Monarquía Hispánica siguieron siendo observados por parte de los dirigentes de la república ${ }^{26}$.

A nuestro modo de ver, un análisis pormenorizado sobre las relaciones hispano-genovesas a partir de la década de 1630 podría ofrecernos una nueva y reveladora perspectiva sobre el proceso de readaptación interior experimentado por la Monarquía Hispánica y sobre el alcance de su desplazamiento en la escena internacional con posterioridad a la paz de Westfalia. Resulta innegable que, a pesar de los efectos negativos derivados de la quiebra financiera y de la caída de sus ingresos, la corona logró conservar, con escasos recortes, la práctica integridad de sus territorios en un marco de sorprendente estabilidad social. Salvo contadas excepciones, como la fracasada rebelión de Mesina de 1674, la fidelidad fue la tónica dominante tanto en Flandes como en los territorios italianos, ibéricos y coloniales de la corona. El amplio margen de autonomía concedido por los delegados reales a las elites locales en el manejo de los asuntos internos y la garantía ofrecida desde Madrid sobre el mantenimiento de sus privilegios e inmunidades eran la mejor prueba de los beneficios que se podían extraer de la relativa debilidad de la corona. Ventajas que resultaban aún más evidentes si se comparaban con las tendencias anexionistas y centralizadoras de su principal rival, Francia, a partir de la década de 1660.

Génova no pareció alejarse demasiado del modelo general seguido por los distintos dominios bajo la jurisdicción del monarca Católico. Los sucesivos planes de rearme naval y de fortalecimiento de su autonomía no dieron los frutos deseados y obligaron a la república a replantear su estrategia. En este sentido, será conveniente observar las limitaciones que impidieron al heterogéneo grupo de los repubblichisti llevar a cabo sus designios navales y romper los estrechos lazos

\footnotetext{
no-genovesas a partir de la década de 1630 ha sido Carlo Bitossi. Además de las obras ya reseñadas, es fundamental su revelador trabajo BITOssI, C.: Il governo dei magnifici. Patriziato e politica a Genova fra Cinque e Seicento, Génova, 199. El resto de las referencias son absolutamente tangenciales incluso en los trabajos sobre el ducado de Milán o sobre los reinos de Nápoles y Sicilia que tan fuertes vínculos mantenían con Génova. Pueden consultarse los apuntes efectuados por Álvarez-Ossorio y Gianvittorio Signorotto en SignorotTo, G.: (ed.), L'Italia degli Austrias. Monarchia catolica e domini italiani nei secoli XVI e XVII, Mantua, 1993 o Álvarez-Ossorio, A.: La república de las parentelas: el estado de Milán en la monarquía de Carlos II, Mantua, 2002 y SignOROTTO, G.: Milano spagnola. Guerra, istituzioni, uomini di governo (1635-1660), Milán, 1996. Por su parte, Domínguez Ortiz, supo ver la importancia de la crisis de 1654 para la posición internacional de la Monarquía, DoMíNGUez OrTiZ, A.: «España ante la paz de los Pirineos», Hispania, XIX, (1959), p. 551.

26 Además del rico material archivístico contamos con la recopilación de las instrucciones y.de los bien documentados informes efectuados por los embajadores y enviados genoveses en Madrid, CIASCA, R.: Istruzioni e relazioni degli Ambasciatori Genovesi. Spagna, Roma, 1951-1957. Vol. III (1636-1655), Vol. IV (1655-1677) y Vol. V (1681-1721).
} 
que ligaban todavía a Génova con la Monarquía o el escaso fundamento de aquellas propuestas que abogaban por un nuevo tipo de alianzas con el resto de las repúblicas del continente. El estudio de la escalada de tensión con las autoridades españolas, que culminaría en 1654 con el secuestro de los bienes genoveses en las posesiones italianas de la corona, nos permitirá comprender tanto lo enraizado de los intereses mutuos que ligaban a las elites de ambos territorios, como el proceso de readaptación experimentado por la alianza hispano-genovesa con posterioridad a dicha crisis. Unas transformaciones que reflejaban de modo palmario la pervivencia de unos vínculos que se habían ido tejiendo desde finales de la Edad Media y que convertían a ambas potencias en las dos caras de una misma moneda.

\section{EL TRIUNFO DE LOS REPUBLIQUISTAS: LA APUESTA POR LA NEUTRALIDAD Y EL PROGRAMA DE REACTIVACIÓN NAVAL}

El descontento provocado en el patriciado genovés por la actitud española durante la guerra de Mantua y por su postura conciliadora hacia las demandas de los sectores populares de la república dio alas a aquellos grupos que, desde finales de la centuria anterior, apostaban por redimensionar los fundamentos de la alianza con la Monarquía Católica ${ }^{27}$.

El impulso experimentado por las finanzas genovesas con posterioridad al medio general de 1577 , del que se aprovecharon por vez primera importantes familias de la nobleza nueva, y el poder alcanzado por los asentistas de galeras al servicio del monarca Católico corrían paralelos a un palpable declive de las actividades productivas, en especial del hasta entonces dinámico sector manufacturero de la seda que, en sus mejores momentos, había llegado a emplear a 35.000 trabajadores $^{28}$. Los excesivos beneficios de unos pocos y su tren de vida aristocrático, como ponen de manifiesto la construcción de imponentes residencias $^{29}$, el aumento del consumo de productos de lujo o la inversión en rentas

27 Como Gioffredo Lomellini que, en un discurso relativo a la cuestión de Finale, adoptó una posición de marcado talante anti-español por lo que aconsejaba buscar una alianza alternativa. Al respecto véase, Costantini, C.: La repubblica di Genova...cit., pp. 220-222. Sobre la publicística genovesa, de fuerte contenido crítico hacia la Monarquía, se puede consultar, SAVELLI, R.: «La pubblicistica politica genovese durante le guerre civili del 1575», Atti della Società Ligure di Storia Patria, XX, 2, (1980), pp. 82-105.

${ }^{28}$ Sobre la industria de la seda SIVORI, G.: «Il tramonto dell'industria serica genovese», Rivista Storica Italiana, 84, (1970), pp. 893-944. Véase también, PACINI, A.: «La repubblica di Genova nel secolo XVI», en Puncuh, D., Storia di Genova...cit., p. 357.

29 Con relación a la renovación urbanística de la ciudad véanse, POlEGGI, E.: Strada Nuova. Una lottizzazione nella Genova del Cinquecento, Génova, 1972 y DORIA, G.: «Investimenti della nobiltà genovese nell'edilizia di prestigio (1530-1630)» en Doria, Giorgio, Nobiltà e investimenti a Genova in Età Moderna, Génova, 1995, págs. 235-285. Las innovaciones introducidas por la aristocracia genovesa en la construcción de palacios y su capacidad para exportar dicho modelo al resto de

Hispania, LXV/1, núm. 219 (2005) 115-152 
feudales en los dominios del monarca Católico, contrastaban con el creciente empobrecimiento del resto de la población y parecían no adecuarse a los tradicionales valores republicanos de la sobriedad, la defensa de los intereses públicos y la exaltación de la independencia y de la autonomía urbanas ${ }^{30}$.

La estrecha colaboración con la Monarquía Hispánica, lejos de favorecer a la república en su conjunto, parecía ir tan sólo en beneficio de un restringido grupo de particulares lo que acentuaba la idea de que las finanzas y los asientos de galeras se constituían en una barrera para el desarrollo productivo y para la puesta en pie de una flota de estado capaz de velar por los intereses de la república. Desde finales de la década de 1580 se fue configurando un complejo frente de hombres de gobierno y de tratadistas políticos que, bajo el apelativo de repubblichisti o de navalistas, propugnaba una revisión de las relaciones con la Monarquía y proponía la puesta en marcha de un proyecto armamentista y de fortalecimiento de los organismos administrativos y de gobierno ${ }^{31}$. Frente a las cuadros simplificadores elaborados por los embajadores españoles, que solían identificar a este grupo de defensores de la autonomía republicana con los sectores menos pudientes de la nobleza nueva ${ }^{32}$, Carlo Bitossi ha subrayado la diversidad de sus orígenes y la inexistencia de un discurso unitario, a pesar de

Europa se pueden observar en la serie de grabados realizada por Rubens y que se publicó en Amberes en 1622. Al respecto véase POLEGGI, E.: «Un documento di cultura abitativa» en Rubens e Genova, Génova, 1977, pp. 85-148. Lo mismo ocurría con los jardines que, como señala Magnani, servían como un instrumento capaz de representar la ambición social y la posición de paridad con el resto de la aristocracia europea por lo que fueron criticados por aquellos que los veían como la mejor expresión del poder de las finanzas sobre el comercio, del modo de vida aristocrático sobre la moderación republicana y que apostaban por «meno ville e fiori e più galee» en MAGNANI, L.: «The Rise and Fall of Gardens in the Republic of Genoa, 1528-1797» en Conan, M. (ed.), Bourgeois and Aristocratic Cultural Encounters in Garden Art, 1550-1850, Washington, 2002, pp. 43-76.

${ }^{30} \mathrm{El}$ contraste entre una Génova dominada por los financieros y carente de autonomía y una Venecia donde primaban el comercio, ya apuntado por Botero, se convirtió en un tópico que se perpetuará, DURAND, Y.: Les républiques au temps des monarchies...cit., p. 151. En 1648, el embajador español en Génova, Antonio Ronquillo señalaba: «El dictamen general es conservar la neutralidad e imaginar esta república tan poderosa como la de Venecia para mantenerla y son pocos los que se libran de esta aprensión pero en inclinarse a Francia son los menos y los de menos caudal y obligación y los más y de porte siguen la inclinación a la corona de España o por su afecto o por sus intereses.» AGS, Estado, leg. 3603, Carta del embajador español, Antonio Ronquillo, sobre la situación de Génova y la posición de las diferentes partes hacia Francia y España, Génova, 28-IV-1648.

${ }^{31}$ La primera referencia que tenemos sobre el uso del término republiquista se la debemos, según Bitossi, al embajador español, Bernardino de Mendoza, que, en 1588, los contraponía a los «otros de sano parecer», BITOSSI, C.: «L'Antico Regime genovese...cit. p. 420.

32 En la rica correspondencia enviada por los embajadores españoles en Génova encontramos una detallada información sobre la posición política de los principales miembros de la aristocracia con respecto a la Monarquía. A cada elección de los colegios o del dux se informa sobre los afectos y desafectos pero, como advierte Bitossi, en la mayoría de los casos dichos informes suelen ser en exceso simplificadores, BITOssI, C.: Il governo dei magnifici...cit. donde analiza las listas remitidas por el embajador Melo en 1633. 
que todos ellos abogasen por romper con la cadena de oro que tenía sometida a la república a los dictámenes procedentes de Madrid ${ }^{33}$.

A partir de 1637, con la elección como dux de Agostino Pallavicini, y hasta la epidemia de peste de 1657, este grupo logró copar las principales magistraturas de la república y, con el apoyo de intelectuales de la talla de Anton Giulio Brignole Sale o Bernardo Veneroso, se propuso llevar a cabo un plan de gobierno destinado a recuperar un pasado glorioso en el que los ciudadanos de la república recobrasen su antigua libertad ${ }^{34}$. Según se recogía en un escrito anónimo, que bajo el ilustrativo título de «La necesidad que tiene la república de armarse y del modo de mantenerse armada» apareció a principios de la década de $1640^{35}$, se establecía un interesante paralelismo entre lo ocurrido a las república griegas, una vez sometidas a la autoridad de Filipo de Macedonia y de Alejandro Magno, y la evolución experimentada por Génova tras el acuerdo entre Andrea Doria y Carlos V. La pacificación de las discordias civiles habría conducido, en ambos casos, a una completa servidumbre y a un desdibujamiento de los principios patrióticos y del cultivo de las armas a cambio de protección y de amplias posibilidades de promoción para una minoría que, atraída por el lujo y las mercedes ofrecidas por el soberano, se alejada paulatinamente de los principios propios de la severidad republicana cultivados por sus mayores ${ }^{36}$. «Genova sono i cittadini uniti, armati, esercitati e coraggiosi», proseguía el escrito, por lo

\footnotetext{
33 Junto a miembros procedentes de lo más conspicuo de la nobleza vieja como Andrea Spinola que, sin poner en cuestión la utilidad de la alianza española, se erigió en el portavoz de un discurso de fuerte contenido moral en defensa de la virtud republicana, encontramos a juristas de extracción social más humilde que, como Raffaele della Torre o Federico Federici, no dudaban en promocionar una política de expansión militar de marcada matriz anti-española con objeto de convertir a la república en una pieza central para asegurar el equilibrio de fuerzas en el continente. SPINOLA, A.: Scritti scelti. Edición de Carlo Bitossi, Génova, 1981.

${ }^{34}$ Para entonces el discurso más moderado de Andrea Spinola había dejado paso al más enérgico de figuras que como Federico Federici, Giambattista Raggio, Gio Bernardo Veneroso, Angostino Pallavicini, Giacomo Lomellini, Alessandro Spinola, Anton Giulio Brignole Sale o Raffaele della Torre, dominaron la escena política e intelectual genovesa entre la décadas de 1630 y 1650 . Al respecto véase, CostantinI, C.: «Politica e storiografia: l'epoca dei grandi repubblichisti» en La letteratura ligure. La Repubblica aristocratica (1528-1797), Génova, 1992, Vol. II, pp. 93-135 así como el ya citado artículo de BiTOssi, C.: «Il tempo degli oligarchi...» que recoge una completa bibliografía y ofrece las referencias básicas sobre las obras de los principales republiquistas.

35 ASCG, Fondo Brignole Sale, Mss. 105-B-7 BS, fols. 327-344.

36 «Io lodo che si stiano deposti gli animi et i rancori che stiano estinte le fazione, che siano gli animi concordi, che si viva con pace nella patria; ma se da questo, sì saporito a tante dolci fonti, doveva derivarne una scordia tanto inetta, un avversion si fatta dagli esercizi militari, un lusso si abominando, come vediamo esser'ora la magior parte dei nostri cittadini quasi che detesti una quiete obbrobriosa no solo ma anche pericolosa, e desiderarei piú presto che col valor dei nostri antenati ci fossero anche rimasti i loro sediziosi capricci nella testa che essendo liberi da questa restar privi di quello. Piú desiderabile, piú glorioso, e piú libero era lo stato delle Repubbliche greche quando tra loro discordi si struggevano che quando da Filippo il Macedone e da Alessandro suo figlio furono pacificate si, ma con una pace, che portò in groppa la servitú» Ibíd.
} 
que la única alternativa consistía en arbitrar determinadas medidas capaces de permitir un mayor grado de emancipación gracias al desarrollo de un poderoso programa de armamento naval y mediante la promoción de nuevas rutas comerciales, en especial en el Levante otomano o en el ámbito ultramarino, a imagen de lo realizado por la república de las Provincias Unidas «che con gran loro profitto hanno eretto le negoziazioni e compagnie dell'Indie Orientali e Occidentali e del Settentrione che sono quelle che mantengono la loro Repubblica e la somministrano le spese eccesive che hanno fatto e fanno in una guerra tanto lunga contro gli spagnoli» ${ }^{37}$. Como ha señalado Haistma Mulier, la imitación del modelo holandés se convirtió en uno de los axiomas de los republiquistas que valoraban su alto grado de autonomía y que veían en sus opulentas compañías de comercio y en su poderosa marina de guerra los únicos instrumentos capaces de erosionar la tutela ejercida hasta entonces por la Monarquía Hispánica sobre Génova ${ }^{38}$. No se trataba, por lo tanto, de sustituir la alianza española por un acercamiento a Francia, de la que se temían sus tendencias anexionistas y su alianza con el duque de Saboya, reafirmada por el tratado de Rivoli en $1635^{39}$. El objetivo consistía en velar por la estabilidad internacional gracias a

37 Lo que además evitaría la salida de numerario y trocaría los préstamos concedidos al monarca Católico y al Pontífice en inversiones en el seno de la república. Por último abogaba por abrirse de nuevo, como había ocurrido durante el glorioso periodo medieval, «nei traffici di Levanțe traslaceranno quelli di Spagna e per conseguenza verrano gli spagnoli a mancar di quelle comoditá che cavano dal danaro de Genovesi.» Ibíd.

${ }^{38}$ Los condicionamientos de la naturaleza podían superarse con la industria por lo que, en el escrito que estamos analizando, se realizaba un cierto paralelismo entre la suerte de todas las repúblicas marítimas que eran capaces de superar las barreras geográficas con la industria. En cierta manera, esa misma geografía se erigía en el principal muro defensivo pues: «Le Provincie e cittá marittime quanto hanno forse che le mantengano il mare libero, non si posono perdere, poichè hanno la porta aperta a soccorsi che facilmente vi posono essere introdotti dagli amici e confederati quando non possino resistere da se stessi». Ibíd. Sobre la necesidad de profundizar en las relaciones entre las Provincias Unidas y Génova véanse las interesantes apreciaciones de HaISTMA MULIER, E.O.G.: «Genova e L'Olanda nel Seicento: contatti mercantili e ispirazione politica» en R. Belvederi (ed.), Rapporti Genova-Mediterraneo-Atlantico, Atti del Congresso Internazionale di studi storici, Génova, 1983, pp. 431-444 así como las indicaciones que hemos realizado en HERrERo SÁNCHEZ, M.: «Las repúblicas mercantiles...cit.

39 Ya en 1631, por la paz de Cherasco, Francia mantuvo su apoyo al duque de Saboya cuyas pretensiones sobre Génova fueron de nuevo incluidas en el tratado de Rivoli de 1635 en el marco de la entrada de Francia en la guerra contra la Monarquía Católica. Todavía en 1649, el embajador español en Génova, Antonio Ronquillo, mostraba su tranquilidad por las escasa viabilidad de una alianza franco-genovesa y señalaba las dificultades que iba a tener Francia para atraerse al resto de las potencias italianas: «Será dificilísimo - apuntaba en una carta remitida a Madrid- el unir los franceses en un mismo punto e intereses diferentes voluntades...porque el día que descubriesen los Príncipes y Repúblicas de Italia esta armazón tratarían de oponerse por todos los medios posibles a ella por serles mucho más peligrosas las fuerzas de mar que las de tierra y por estar tan temerosos de las fuerzas de Francia, de sus vastos designios y de su intolerable ambición.» AGS, Estado, leg. 3604, Carta de Ronquillo, Génova, 11-I-1649.

Hispania, LXV/1, núm. 219 (2005) 115-152 
un acuerdo con el resto de las repúblicas del continente cuyos intereses mercantiles les inclinaban de manera inevitable hacia la paz.

Esta decidida apuesta por una neutralidad activa y el deseo de los nuevos gobernantes de la república de actuar con voz propia en el escenario internacional no podían llevarse a cabo sin el desplazamiento de aquellos grupos que mayores intereses tenían depositados en el mantenimiento de buenas relaciones con la Monarquía Hispánica y que, hasta el momento, habían dirigido los destinos de la república. Se trataba de limitar el poder de los asentistas de galeras poniendo barreras a los privilegios de que habían gozado en el abastecimiento de pertrechos y en el uso del puerto ${ }^{40}$, de diversificar el destino de los capitales genoveses dirigiéndolos hacia otras plazas ajenas al dominio español y de intentar limitar la adquisición de feudos y otro tipo de rentas en los dominios de la Corona. Además, era necesario recortar las prebendas de las que gozaban los miembros más distinguidos del partido español, esto es, aquellas familias que como los Doria o los Spinola habían logrado acceder a la Grandeza de España gracias a los servicios financieros y militares prestados al monarca Católico. Figuras como el duque de Tursi, principal asentista de galeras de la Monarquía, o el marqués de los Balbases, miembro del Consejo de Estado y uno de los más influyentes personajes en la Corte española durante el valimiento de Luis de Haro, sufrirán el acoso de las autoridades genovesas pues, como señalaba el embajador español, Antonio Ronquillo: «el fin de esta república es bajar estas tres casas del Príncipe Doria, duque de Tursi y marqués de los Balbases no pudiendo sufrir su grandeza que haya desigualdad de ellas a las demás» por ir en contra de las leyes unitarias de la nobleza acordadas en $1528^{41}$.

40 En 1655, momentos después de la grave crisis de 1654, la república le quitaba al duque de Tursi la logietta de la que disponía en la dársena del puerto para guardar los pertrechos de las galeras que tenía al servicio del rey, AGS, Estado, leg. 3608, Carta del secretario de la embajada, Diego de Laura, Génova, 9-VIII-1655.

${ }^{41}$ AGS, Estado, leg. 3604, Carta de Ronquillo sobre la resolución adoptada por los colegios de visitar la casa del duque de Tursi, medida que había provocado importantes críticas en la ciudad: «el pueblo universalmente lo ha sentido mal y si el duque tomara alguna resolución grande hallará hartos en él que la siguieren.», Génova, 12-XII-1648. En otra carta, con fecha del día siguiente, proseguía: «De esta locura, en que son pocos los que no hayan caído ha nacido que muchos se persuaden a que el Príncipe Doria, duque de Tursi, y Marqués de los Balbases son menos por Grandes que por ciudadanos genoveses y ha muchos días que procuran mortificarlos y que se entienda que el grado de Grandeża no les hace nada en Génova y que han de pasar por la medida de los demás ciudadanos» AGS, Estado, leg. 3604, Carta de Antonio Ronquillo, Génova, 13-XII-1648. Por su parte, el embajador genovés en Madrid abordaba este asunto desde otra perspectiva e identificaba a aquellos que con más energía habían mostrado sus quejas en la Corte por el trato otorgado a Tursi y Balbases: el marqués de Leganés, cuñado de este último, y el conde de Peñaranda para los que: "questi trattamenti che se li fanno non procedeno da non esser costì superiorità dei cittadini ma per esser loro ministri e devoti della Corona di Spagna», Archivio di Stato di Genova (ASG), Archivio Segreto, leg. 2448, Carta de Paolo Vicencio Spinola, Madrid, 1-II-1653. El asunto siguió dando juego. De nuevo en 1662, y con ocasión de una serie de agravios realizados contra la casa del Príncipe Doria, Diego de Laura, secretario de la embajada española en Génova, volvía a indicar que lo

Hispania, LXV/1, núm. 219 (2005) 115-152 
El hostigamiento hacia estos mediadores «eminentes», a los que se acusaba de llevar un tren de vida poco acorde con los principios de sobriedad y frugalidad propios de la mediocritas republicana ${ }^{42}$, se enmarcaba en una agenda de gobierno que apostaba por una intensa renovación de la república a través de la aplicación de medidas enérgicas capaces de limitar el margen de maniobra de los particulares y de reforzar la acción de los organismos de gobierno. Un fortalecimiento del poder del estado que, en consonancia con el discurso mercantilista en boga en Europa, se tradujo en una activa política de obras públicas y en la puesta en marcha de iniciativas destinadas a potenciar los intercambios mercantiles y a proteger los intereses manufactureros y comerciales de la república. La construcción de la nueva muralla, entre 1626 y 1634 , y del acueducto, las profundas reformas acometidas en la dársena del puerto ${ }^{43} \mathrm{o}$ los intentos de convertir Génova en un lugar atractivo para el resto de los comerciantes extranjeros, mediante la puesta en marcha de un puerto franco que permitiese desplazar a Livorno como principal núcleo de intercambios en la zona ${ }^{44}$, estuvieron acompañados por la aplicación de una rigurosa, aunque poco efectiva, legislación suntuaria $a^{45}$ y por un programa de promoción naval que exigía un considerable esfuerzo presupuestario y un inevitable aumento de la presión fiscal ${ }^{46}$.

que se pretendía con estas medidas era que: «se dé a entender que ni tienen privilegios, ni se les debe obsequio ni inmunidad alguna y que han de ser iguales y aún inferiores a cualquier ciudadano", AGS, Esado, leg. 3610, Carta de Diego de Laura sobre el apresamiento de un criado del Príncipe Doria, Génova, 30-VIII-1662.

${ }_{42}$ BITOSSI, C.: Il governo dei magnifici...cit.,, p. 199.

43 Doria, G. y PIERgiovanni, P.M. (eds.): Il sistema portuale della repubblica di Genova. Profili organizzativi e politica gestionale (secc. XII-XVIII), Génova, 1988.

${ }_{44}$ Un buen análisis sobre las vicisitudes para la puesta en marcha de un puerto franco en 1654 , con una interesante comparación con otros modelos semejantes en Europa, en especial con el de Livorno, la tenemos en KIRK, T.: Genoa and the Sea: Ships and Power in the Early Modern Mediterranea (15591680), Tesis doctoral inédita, Instituto Universitario Europeo de Florencia, 1996, pp. 271-304 y KIRK, T.: «Genoa, Livorno: Sixteenth and Seventeenth-century Commercial Rivalry as a Stimulus to Policy Development», History, 86, 281, (2001), pp. 3-17. Sobre la actividad del puerto de Génova son fundamentales las aportaciones de GRENDI, E.: La repubblica aristocratica dei genovesi, Bolonia, 1987, en especial el artículo relativo a la actividad de los comerciantes noreuropeos entre 1590 y 1666.

${ }^{45} \mathrm{~A}$ pesar del interés con el que las autoridades genovesas abordaron las cuestiones relativas a la difusión del lujo, no encontramos una normativa suntuaria efectiva hasta 1671 , cuando se vuelve a recuperar la fuerte actividad legislativa de finales del siglo XVI, CAPODONICO, C.: «Normative suntuarie e pratiche sociali nella Genova moderna: le dinamiche della moda del vestire e dell'abitare», Miscellanea Storica Ligure, XVIII, (1986), pp. 105-132.

46 Presión fiscal que, según se apuntaba en el texto relativo al rearme naval de Génova sobre el que ya hemos hecho referencia, poco tenía que ver con la practicada por los sistemas dinásticos y que se justificaba de esta manera: «quando si tratta d'imposizioni moderate e che queste debbano servir al ben pubblico al difender la patria all'ovviar a un evidente periglio a mantener la libertá, siccome sono necesarie così le stimo anche lodevoli, non che lecite e giuste et ognuno deve concorrervi...Nelle Repubbliche le imposizioni e taglie sminuiscono le facoltá dei privati ma con mantener la libertá col difendersi dalle tirannie de stranieri con lo metterci in reputazione, con lo agevolare i traffici ce le accrescono. Nel 
La necesidad de garantizar de modo autónomo la independencia de la república, de ejercer un estricto control sobre las aguas de la Liguria y de luchar de manera eficaz contra el corsarismo, que se acentuó con la entrada de Francia en la guerra de los 30 años, impulsaron la creación, en 1638, de la Compagnia di Nostra Signora di Libertà. A pesar de la férrea oposición de los poderosos armadores privados que, en calidad de asentistas de galeras, constituían uno de los más importantes grupos de presión a favor del sostenimiento de la alianza española, la república pretendía reactivar el espíritu marinero del pasado a través de una flota pública de galeras con una tripulación asalariada ${ }^{47}$. Aunque el resultado fue desalentador, el grupo de los navalistas siguió promocionando este tipo de iniciativas. A la fundación de la Compangia Genovese delle Indie Orientali en 1647, cuya tripulación y bastimentos procedian de las Provincias Unidas ${ }^{48}$, siguió, a finales de la década de 1650 , la de la Compagnia marittima di San Giorgio que tenía como objetivo abrir a los genoveses el acceso a los mercados brasileños, provocando el recelo de la Monarquía Hispánica que, por entonces, se encontraba en pleno conflicto con Portugal. Más éxito tuvo la puesta en funcionamiento, a partir de 1655 y hasta la década de 1680 , de un convoy formado por varios galeones, comprados también en Ámsterdam, que, salvo

caso nostro l'imposizioni non possono essere esorbitanti. Non hanno le Repubbliche bisogno di tanto danaro, di quanto hanno bisogno i Principi. Questi sono necessitati a mantener le genti alla loro devozione col pagar profusamente, col donar largamente; Nelle Repubbliche i cittadini travaglian volontieri per poco, sapendo che lo fanno per la sua patria, per il suo onore, e per se stessi.» En ASCG, Fondo Brignole Sale, Mss. 105-B-7 BS, Della necessità che ha la repubblica di Genova di armarsi e del modo di mantenerla armata, $s / f$ de principios de la década de 1640 .

47 Sobre el nuevo armamento es fundamental el artículo de BITOSSI, C.: «Navi e politica nella genova del Seicento", Atti della Accademia Ligure di Scienze e Lettere, serie VI, V, (2002), pp. 261283. En este contexto, no es de extrañar el acoso paralelo contra los principales representantes de los armadores de galeras. Junto a las limitaciones de los privilegios que ostentaba el príncipe de Tursi, y que ya han sido reseñados, se actuó con dureza contra su hijo, Juanetín Doria, por haber dado la precedencia a las galeras de Nápoles, que estaban a su mando, sobre la escuadra de galeras de la república. En una acuerdo alcanzado casi por unanimidad, y a pesar de las instancias del embajador español, le fueron arrebatados los privilegios de que gozaba como miembro de la familia Doria así como el trato de Magnífico, situación que le permitía afirmar al embajador Ronquillo que: «ya se camina tan declaradamente a la descomposición de esta casa que dicen con publicidad que mientras no se fueren de Génova han de recibir mayores desaires sin perdonar la ocasión de hacérselos.» AGS, Estado, leg. 3604, Carta de Ronquillo, Génova, 10-IV-1649. El Consejo de Estado estudió la situación y exigió responsabilidades a la república por acosar a una persona al servicio del rey, AGS, Estado, leg. 3274, Consulta del Consejo de Estado sobre el asunto de Juanetín Doria, Madrid, 5-V-1651.

${ }^{48}$ KIRK, T.: «A Little Country in a World of Empires: Genoese Attempts to Penetrate the Maritime Trading Empires in the Seventeenth Century»; The Journal of European Economic History, 25, no. 2 (1996), pp. 407-421; PresotTo, D.: «Da Genova alle Indie alla metà del Seicento. Un singolare contratto di arruolamento marittimo» en Atti della Società Ligure di Storia Patria, IX, 1, (1969), pp. 69-91 y SUBRAHMAYAM, S.: «On the significance of Gadflies: the Genoese East India Company of the 1640s", Journal of European Economic History, 17, no. 3 (1988), pp. 559-581.

Hispania, LXV/1, núm. 219 (2005) 115-152 
dos viajes al Levante otomano en 1666 , tuvo por objeto la protección del comercio con España y, más en concreto, con el puerto de Cádiz ${ }^{49}$.

El talante dirigista de todos esto proyectos, que poco tenía que ver con el modelo de compañía comercial holandés que había sido tomado como ejemplo, atestiguaba el carácter autoritario y, en cierto sentido, intervencionista de las medidas adoptadas desde finales de la década de 1630. A pesar de los llamamientos destinados a potenciar la solidaridad con el resto de las repúblicas europeas, los nuevos gobernantes genoveses prefirieron inclinarse, como mejor método para reafirmar su soberanía y su completa autonomía con respecto a Madrid, por la adopción de un lenguaje más cercano al de los sistemas dinásticos preponderantes que al de sus equivalentes republicanos. El dominio que ejercía sobre el reino de Córcega animó al gobierno de la república a adquirir, en 1637, la dignidad regia y a nombrar a la Virgen María como reina de Génova con la intención de obtener un mayor reconocimiento internacional y una serie de ventajas protocolarias ${ }^{50}$. El reconocimiento de la autoridad regia llevaba implícita una cierta admiración por parte del grupo dirigente genovés hacia las formas autoritarias de gobierno. Sólo así podemos comprender los argumentos utilizados por Brignole Sale durante su embajada en Madrid en 1646 cuando, para convencer a Felipe IV de la necesidad de reconocer el título regio, afirmaba con rotundidad: «¿Qué menester son aquí más consultas de ministros, ni de Consejos? ¿No es Vuestra Majestad soberano señor de todo? ¿No tiene absolutísima autoridad? ¿No puede hacer lo que quiere de por si solo? ¿No lo debe hacer cuando es tan clara la razón y las conveniencias? Por lo demás es grandísima fineza de la real prudencia que el príncipe de cuando en cuando haga resoluciones totalmente de por sí solo para mostrar y ejercitar enteramente el brío de su voluntad y la soberanía de su poder» ${ }^{51}$.

La frontal oposición a dicho reconocimiento por parte de la Monarquía, que seguía erigiéndose en protectora y defensora de la libertad de la república, suscitó un sinfín de altercados diplomáticos por cuestiones de tratamiento y una avalancha de memoriales en los que se exponían los derechos de ambas partes y se llegaban, incluso, a efectuar amenazas veladas como prueba de descontento en caso de no atenderse los requerimientos mutuos. En su denuncia por el acoso al que fueron sometidas por parte de las autoridades de la república aquellas

49 CalCagno, C.G.: «La Navigazione convogliata a Genova nella seconda metà del Seicento.» Miscellanea Storica Ligure. Nuova Serie Periodica III, no. 1 (1971): 267-391.

so $\mathrm{El}$ primer dux que fue coronado según el nuevo ceremonial fue Agostino Pallavicini, el líder de los novatori. El palacio ducal pasó a ser denominado Palacio Real y se acuñaron monedas con la corona regia. BITOSSI, C.: «L'Antico Regime genovese...cit., pp. 447-448.

51 ASG 2003, Archivio Segreto, leg. 2447, Memorial de Anton Brignole Sale a Felipe IV, Madrid, 8-IV-1646. Por lo tanto, no le faltaba razón a Costantini cuando afirmaba incisivo que, frente al discurso republicano mantenido por Andrea Spinola, para mediados de la centuria los novatori o republiquistas hablaban cada vez menos de libertad y cada vez más de príncipe, CosTANTINI, C.: La repubblica di Genova...cit., p. 296. 
familias más cercanas a los intereses españoles, el embajador, Antonio Ronquillo, se lamentaba a finales de 1648 , en estos contundentes términos, del desagradecimiento mostrado por «los mozos y los que ahora tienen mano en los colegios» por haber llevado a la república: «a tal punto de vanidad y altivez que se olvidaba de sus principios y de las desventuras que en diversos tiempos ha padecido con la riqueza a que han venido los particulares con la paz de que gozan y, con la satisfacción de que su buen gobierno los mantiene en felicidad, se tienen por superiores a todos los príncipes y que pueden igualarse a los mayores monarcas» ${ }^{52}$. El recibimiento que debía otorgarse a Mariana de Austria a su paso por el territorio de la república para contraer matrimonio con Felipe IV agudizó el conflicto al solicitar las autoridades genovesas que los 4 senadores enviados para recibirla pudiesen cubrirse ante la reina. Ante esta exigencia, se optó por realizar el embarque en Finale en lugar de por el más adecuado puerto de Génova para, en palabras del conde de Monterrey, ofrecer «descortesías a descortesías» ${ }^{53}$.

El ambiente siguió enrareciéndose debido a la venta del enclave de Pontremoli al Gran Duque de Toscana, a pesar del acuerdo alcanzado previamente con la república ${ }^{54}$, y por las vejaciones a las que, en comparación con el trato

52 «De donde - proseguía - nace que juzgan por la mayor grandeza ser ciudadanos de Génova y no se avergüenzan de decir delirios, antes aplaudiendo una proposición que Rafael Torre hizo en un memorial para pedir la Sala Regia de que era más debida a la embajada de la república que a la de ningún rey porque los embajadores de los reyes son vasallos de quien los envía y los de la república parte del mismo príncipe.»AGS, Estado, leg. 3604, Carta de Ronquillo, Génova, 13-XII-1648.

53 BNM, Mss. 2380, Carta de Antonio Ronquillo y Briceño sobre el recibimiento de la reina en Génova, Génova, 23-VII-1649. El agravio que suponía para Génova el paso de la reina por Finale se había visto precedido por otro roce protocolario. El enviado genovés que había acudido a Milán para rendir homenaje a Mariana de Austria fue obligado por parte del gobernador, el marqués de Caracena, a retirar dos de los caballos de una carroza de seis al grito de: «se quiten los caballos que todo el mundo lo vea». Situación que provocó las quejas del delegado de la república en Madrid, Pallavicini, que elevó un memorial al rey en el que afirmaba: «di questa azione inescusabile quanto inaudita è rimasta altamente offesa la mia repubblica nella delicta pupilla della sua reputazione.» ASG, Archivio Segreto, leg. 2447, Memorial de Pallavicini, Madrid, 30-VII-1649. Sobre el paso de los miembros de la familia real por Génova véase, STAGNO, L.: «Sovrani spagnoli a Genova: entrate trionfali e 'hospitaggi' in Casa Doria» en BOCCARDO, P., COLOMER, J.L. y Di FABIO, C. (eds.): Genova e la Spagna...cit., pp. 73-88.

54 ASG, Archivio Segreto, 2447, Informe de De Mari, Madrid, 14-II-1650, se recogen la quejas elevadas por el embajador genovés en Madrid, De Mari, contra el libelo publicado en Milán por Nicolás Fernández de Castro que contenía un tono muy agresivo contra la república y en el que se daba marcha atrás en la venta de Pontremoli que había servido a la Monarquía para salvar Milán en una coyuntura bélica muy delicada. Don Luis de Haro le ofrece las garantías necesarias sobre la restitución del dinero adelantado que, como probaba la oferta del Gran Duque de Toscana, había sido inferior al coste del enclave. Sobre la cuestión de Pontremoli véase también, AGS, Estado, leg. 3606, Consulta del Consejo de Estado sobre un memorial de Stephano De Mari, Madrid, 9-II-1651 y BNM, Mss. 6249, Breve discorso giuridico politico di Francesco Arnolfi sopra il contratto della vendita di Pontremoli celebrato dal signor Condestable, governatore dello Stato di Milano, con la

Hispania, LXV/1, núm. 219 (2005) 115-152 
ofrecido a los naturales, se veían sometidos aquellos genoveses que poseían rentas en el reino de Nápoles ${ }^{55}$. Ante este cruce de agravios, la república adoptó las medidas pertinentes para, según se advertía en un opúsculo titulado Advertencias del procedimiento y fines con que camina la república de Génova, hacer gala, frente el resto de Europa, de su emancipación con respecto a su antigua protectora y de su voluntad de mantener «una neutralidad igual entre las dos corona de España y de Francia» ${ }^{56}$. La dependencia española con respecto al crédito genovés otorgaba a la república un mayor margen de maniobra debido a la convicción de que, como se indicaba en dicho escrito: «sin los asientos que hacen, no puede Vuestra Majestad mantener sus reinos» ${ }^{57}$. El embajador español en Génova, que hasta entonces había ejercido el papel de garante de las privilegiadas relaciones de la república con Madrid, fue despojado paulatinamente de determinados privilegios de los que había gozado hasta el momento: en las recepciones oficiales se eliminaría la tarima que le permitía mantener su silla a la misma altura que la del dux; no se le volvería a convocar en las procesiones públicas y se imponía una multa de 200 escudos de oro a todo aquel ciudadano que entrase en su casa sin permiso de las autoridades de la repúbli$\mathrm{ca}^{58}$. Medidas que se presentaban como la mejor prueba del alto grado de autonomía alcanzado por Génova en el escenario internacional.

repubblica di Genova, Milán, 12-V-1649, fols. 52-64. Esta cuestión es abordada por SiGNOROTTO, G.: «Il marchese di Caracena al governo di Milano (1648-1656)» en Signorotto, G., (ed.), L'Italia degli Austrias...cit., pp. 148-149.

5s Ante las quejas realizadas por el enviado genovés en Nápoles, Filippo Spinola, para que no se estableciese ninguna diferencia entre forasteros y napolitanos a la hora de gozar de las rentas en el reino de Nápoles (ASG, Archivio Segreto, leg. 2447, Memorial de Spinola al duque de Oñate sin fecha pero incluido en un informe enviado desde Génova al embajador en Madrid, Pallavicino, Génova, 18-I-1649) Felipe IV notificó a su virrey que se volviese a implantar el trato igualitario introducido por el duque de Medina de las Torres, ASG, Archivio Segreto, leg. 2447, Carta del rey al duque de Oñate, Madrid, 5-VI-1649. El año anterior, el embajador Ronquillo había enviado un memorial a Madrid en el que se arbitraban una serie de medidas destinadas a privilegiar a los comerciantes napolitanos sobre los genoveses con importantes ventajas fiscales gracias a las cuales: «ya no irán más dineros a Génova que los de los asentistas y se enriquecerán los vasallos del rey e irán a Nápoles dos millones de reales que son los que todos los años van a Génova y vendrán a Cádiz mercaderes de Nápoles que hasta ahora no se les ha visto.» AGS, Estado, 3603, Arbitrio enviado por Ronquillo a Madrid, Génova, 20-VIII-1648.

56 AGS, Estado, leg. 3604, Memorial sin fecha anexo a una Consulta del Consejo de Estado de abril de 1649 sobre varias cartas y documentos enviados por Ronquillo.

57 Como se desprende del minucioso estudio de Carmen Sanz, entre 1650 y 1665 los genoveses ocupaban todavía el $57 \%$ de las operaciones de préstamo hechas en plata y el $23 \%$ de las efectuadas en vellón donde tan sólo eran superados por los portugueses. SANZ AYÁN, C.: Los banqueros de Carlos II, Valladolid, 1988, pp. 196-198.

58 AGS, Estado, leg. 3604, Advertencias del procedimiento y fines con que camina la república de Génova, s/f.

Hispania, LXV/1, núm. 219 (2005) 115-152 


\section{LOS LÍMITES DE LA AUTONOMÍA GENOVESA Y LA CRISIS DE 1654}

"Querer la república correr pareja con la Corona de España es locura y desatino y que puede dar mal ejemplo a los demás príncipes de Italia por lo que conviene atajar un inconveniente tan grande» se advertía en un duro alegato anónimo manejado por el Consejo de Estado en Madrid para estudiar la respuesta que debía adoptarse ante el creciente desafío genovés ${ }^{59}$. En primer lugar, y como contrarréplica capaz de mantener intacta la reputación del soberano, se impediría a cualquier súbdito de la república el acceso a la residencia de los ministros del rey sin licencia de los virreyes o gobernadores so pena de 400 escudos y se sometía a un rígido control el uso de la despensa de su embajada en Madrid. En lugar de recurrir a una ruptura de hostilidades que podría poner en peligro la seguridad de Milán, se optaba por aplicar medidas concretas que afectasen a aquellas familias que mayor animadversión mostraban hacia la Monarquía en sus intereses particulares. Algo para lo que, según advertía el marqués de Caracena: «Vuestra Majestad solo en el mundo tiene otros medios de mortificarlos sin romperle pues en ningún otro estado hay tantos genoveses ni tienen la hacienda que tienen en los de Vuestra Majestad ${ }^{60}$ Además de proceder al alojamiento obligatorio de efectivos militares en los feudos genoveses en Italia, se apostaba por reforzar el puerto de Finale y por desviar en esa dirección el comercio de la sal destinada al ducado de Milán que constituía una de las principales rentas fiscales para la república. Por último, se arbitraban determinados mecanismos de control capaces de atajar el fuerte contrabando genovés en los puertos de la Monarquía y, de forma especial, en la costa valenciana y en Cádiz donde se producían las mayores extracciones de metales preciosos, tanto por parte de los mercaderes particulares como de las galeras que actuaban al servicio del rey ${ }^{61}$.

59 AGS, Estado, leg. 3604, Informe anónimo sobre las relaciones entre España y Génova. Sin fecha pero sometido a estudio en una reunión del Consejo de Estado de abril de 1649.

60 AGS, Estado, leg. 3604, Carta del marqués de Caracena sobre la actitud que se debe tener con los genoveses, Milán, 3-VIII-1649. La primacía de los intereses particulares sobre los generales propio de las repúblicas mercantiles era subrayada por Ronquillo a propósito de la solicitud de perdón realizada por Bernabé Centurione, que había sido castigado por el marqués de Caracena con el envío de un regimiento de dragones a unos lugares suyos en el Montferrato. Medida que se había mostrado efectiva «Con que -en palabras de Ronquillo- ha quedado bien escarmentado y otros advertidos y es menester entender que a genoveses ningún beneficio les obliga y que el miedo y sus intereses es quien los rige y que por diez ducados que se atraviesen negará el padre al hijo», AGS, Estado, leg. 3604, Carta de Ronquillo, Génova, 31-I-1649.

${ }^{61} \mathrm{El}$ apresamiento, en septiembre de 1651, de una galera al mando del duque de Tursi en el puerto de Cartagena con gran cantidad de plata sin registrar era la prueba de la dureza con la que empezaron a actuar, a partir de entonces, los veedores de contrabando en los puertos españoles en contra de los intereses de la república, véase Archvio di Stato di Firenze (ASF), Mediceo del Principato, Carta del enviado toscano en Génova, Gio Battista Cinatti en la que informa que «i ministri reggi l'avevano fatto sbarcare tutte queste robe sotto pretesto che nella galera ci fossero denari di contrabbando. Questa è la rovina di questa piazza e di tutta la contrattazione.» Génova, 15-IX-1651.

Hispania, LXV/1, núm. 219 (2005) 115-152 
La alternativa que, en calidad de transportistas, ofrecían los mercaderes holandeses, a los que se les habían concedido un buen número de privilegios con motivo de la paz de Munster, permitía a la Monarquía actuar con mayor rigor y ponía en peligro la posición de los genoveses en la distribución de aquellos productos que, como la seda o el trigo sicilianos y napolitanos o los vinos españoles, constituían una pieza clave para el buen funcionamiento de su emporio mercantil ${ }^{62}$. Los lazos que ligaban a la república con la Monarquía no respondían tan sólo - como pretendían los republiquistas - a los intereses de los grandes prestamistas, de los armadores de galeras o de aquellas familias que, en su mayoría procedentes de la nobleza vieja, mantenían feudos y rentas en los estados del rey Católico y que observaban con temor las constantes amenazas de embargo de sus bienes realizadas por los ministros del rey. Los territorios de la Monarquía Hispánica además de abastecer a la república de plata y productos agrarios constituían el mercado principal para la exportación de lo que aún quedaba de la manufactura genovesa, en especial el papel y la seda, lo que explica la animosidad con la que se observaba, por parte de los sectores populares y del artesanado, el empeoramiento de relaciones con Madrid ${ }^{63}$.

La Monarquía contaba, por lo tanto, con suficientes garantías como para poder limitar con éxito los intentos autonomistas genoveses y para poner barreras a los deseos de la república de tejer un entramado de alianzas alternativo. Más aún cuando los acontecimientos pusieron de relieve que aquellas propuestas destinadas a estrechar los vínculos con las otras repúblicas hermanas carecían de fundamento. El temor con el que se observaron en Génova los levantamientos en Nápoles y Sicilia en 1647 respondía a los arraigados intereses genoveses en la zona y al recelo con el que, figuras tan destacadas en el proyecto republiquista como Raffaele della Torre, acogieron los excesos revolucionarios de la plebe. La colaboración naval prestada por la república resultó fundamental para sofocar las revueltas. Junto a las escuadras de galeras al mando del duque de Tursi, que se dirigieron a Nápoles, la república decidió enviar las 11 galeras del nuovo ármamento a Sicilia por lo que, en lugar de servir para fortalecer la autonomía de la república con respecto a Madrid, habían acabado por constituirse en un elemento crucial para mantener la posición española en el Mediterráneo occidental ${ }^{64}$.

La solidaridad y la teórica colaboración entre los regímenes republicanos chocaba con la fuerte rivalidad existente por el control de los mercados más lucrativos. En lugar de como aliadas, las republicas acabaron comportándose como feroces competidoras y llegaron incluso a enfrentarse por cuestiones protocolarias del mismo modo que lo hacían los regímenes monárquicos preponderantes ${ }^{65}$. La

\footnotetext{
62 Sobre la rivalidad comercial entre Génova y las Provincias Unidas en los mercados hispanos véase, HERRERO SÁNCHEZ, M.: El acercamiento hispano-neerlandés...cit., pp. 304-307.

63 Costantini, C.: La repubblica di Genova...cit., p. 348.

${ }^{64}$ KIRK, T.: Genoa and the Sea...cit., p. 227.

6s Sobre la rivalidad entre los sistemas republicanos europeos y los límites de una teórica internacional republicana véanse las advertencias efectuadas por VENTUR, F.: Utopia e riforme...cit., p. 36
} 
pretensión de Génova de ver reconocido su título regio no fue sólo denegada por el monarca Católico o por el Pontífice ${ }^{66}$ sino que tampoco encontró el eco esperado en las Provincias Unidas. Como señalaba Stephano d'Andrea desde el consulado de la república en Ámsterdam, los holandeses no tenían reparo en aceptar que los representantes genoveses se cubriesen delante de los tribunales o de los burgomaestres pero no así cuando se encontraban en La Haya ante la Asamblea de los Estados Generales ${ }^{67}$. Mayor dureza mostraron cuando se trató de hacer frente a toda posible injerencia en sus mercados. El plan de expansión colonial auspiciado por el gobierno genovés mediante la creación de la Compagnia Genovese delle Indie Orientali, cuyos navíos habían sido construidos en Texel, llegó a su fin en 1649 debido al rechazo de su homóloga holandesa a ceder un ápice en su teórico monopolio en aguas asiáticas. Dos años después de su puesta en marcha, los dos barcos de la compañía y su rica carga fueron confiscados en el puerto de Batavia ante la pasividad del gobierno de las Provincias Unidas ${ }^{68}$. Este tipo de encontronazos se produjo asimismo con Venecia que observaba con fuerte pre-

\footnotetext{
y las sugerencias que realizamos en HERRERO SÁNCHEZ, M.: «Las repúblicas mercantiles, calternativa al modelo dinástico?...cit. pp. 220-227.

66 En 1690 el embajador francés en la república subrayaba como uno de los mayores errores del gobierno genovés el haber «empeorado en los actos de la prudencia y política o sea por la vanidad de los títulos y formas con que ha pretendido ser tratada en las cortes extranjeras.» BNM, Mss. 11021, Reflexiones hechas al rey por su embajador en Génova por los años 1690 y medios que juzgaba convenientes para conquistarla, fol. 127. Postura de fuerza que contrastaba con la posición más condescendiente mostrada por Lionne cuando, a su paso por Génova poco tiempo después del embargo de bienes genoveses de 1654 , y cuando Francia apostaba todavía por una política de acercamiento y no de sometimiento hacia la república, se erigía en valedor de dichos derechos y criticaba la postura de Madrid: «de sottoporre lo standarto della repubblica a trattamento inferiore al suo grado et possesso con no permettere anche oggi ai suoi ambasciatori di coprirsi dove si coprino alcuni sudditi e cittadini» BNM, Mss. 2384, Discorso alla serenissima repubblica di Genova fatto a nome del re Cristianissimo nel mese di gennaio nell'anno 1655 da Monsieur de Lionne, fol. 315.

${ }^{67}$ Además continuaba d'Andrea: «i consoli non godono qui privilegio ne essenzione alcuna pagando tutti i diritti e soggiacendo alla giustizia ordinaria.», ASG, Archivio Segreto, leg. 2657, Carta de Stephano d'Andrea sobre el tratamiento que reciben los cónsules extranjeros en Holanda, Ámsterdam, 12-II-1671.

${ }^{68}$ Como hemos visto, los navíos necesarios, tanto para los proyectos coloniales o para la lucha contra la piratería berberisca y la puesta en marcha del convoy establecido en 1655, habían sido construidos en Holanda, situación que provocó un sinfín de problemas pues las autoridades neerlandesas los retuvieron argumentando que el conflicto con Inglaterra no hacía conveniente la salida de efectivos navales fuera de la república. Las quejas del enviado genovés, Giovanni Stephano Spinola y de su gobierno mantuvieron siempre un tono de gran corrección. La dependencia de los astilleros neerlandeses lo hacía aconsejable: «Le signorie VV.EE. e Potentissimi hanno si formidabili armate che, a loro, due navigli piú o meno non sono in maniera alcuna considerabili; dove per lo contrario noi, che finora abbiamo usato per le nostre occorrenze Galee e non navi, abbiamo necessità di provvederci di nuove forze contro i corsari che navigano con navi e non con galee.», Algemeen Rijksarchief, La Haya (ARA), Staten-Generaal, leg. 6907, Carta a los Estados Generales, Génova, 8-V-1653. Sobre este asunto véase también la correspondencia de Spinola almacenada en ASG, Archivio Segreto, leg. 2335, en especial la carta enviada desde La Haya, 5-IX-1653.
}

Hispania, LXV/1, núm. 219 (2005) 115-152 
vención los intentos genoveses para abrirse un espacio en el Levante aprovechando el conflicto que mantenía con la Sublime Puerta. Por el contrario, el final de sus turbulentas relaciones con la Monarquía Hispánica a partir de mediados de la centuria permitió a los venecianos reforzar sus contactos mercantiles con el ducado de Milán y con el reino de Nápoles en detrimento de los hombres de negocios genoveses ${ }^{69}$.

El elevado coste de las medidas propugnadas por los navalistas para alcanzar un más alto grado de autonomía con respecto a Madrid supuso un consistente aumento de la presión fiscal y creó un poso de descontento que, al igual que ocurrió por esas fechas en el resto de Europa, abonó el terreno para el estallido de los movimientos de protesta. El final de la relación privilegiada con la Monarquía Hispánica, como había pronosticado con agudeza Andrea Spinola, abrió el camino a una mayor intromisión de otras potencias extranjeras en las disputas internas de la república. A partir de 1646, se sucedieron una serie de complots y de conjuras que, como la protagonizada en 1648 por Gian Paolo Balbi, contaron con el sostén de Francia y estuvieron a punto de hacer resucitar los choques de facciones que habían asolado la república con anterioridad al acuerdo de $1528^{70}$.

El empeoramiento de las relaciones hispano-genovesas se elevó de tono con la agudización del latente conflicto sobre el marquesado de Finale. El incremento de la actividad corsaria por parte de los armadores que, con licencia del monarca Católico, operaban desde dicho enclave trababa la normalidad de los intercambios en las aguas de la Liguria sobre las que la república pretendía ejercer la completa soberanía. Génova exigía también el reconocimiento del monopolio que, desde 1571, ostentaba sobre el abastecimiento de sal en el marquesado y el pago de las alcabalas que, en calidad de «señora del mar desde Corbo hasta Mónaco» debían pagar todas la naves que operasen en dicha zona, a pesar de las quejas de los finalinos que se consideraban súbditos del duque de Milán ${ }^{71}$. El conflicto se agravó ante el propósito del marqués de Caracena, go-

69 ASG, Secretorum, Intentos genoveses por recuperar el control sobre el abastecimiento de sal a Milán que «i veneziani han procurato di tirarlo a loro», Génova, 19-II-1657.

70 Según advertía Antonio Ronquillo: «el odio y enemistad entre facciones de esta república va creciendo cada día y es milagro que no se desconcierte todo.» En AGS, Estado, leg. 3604, Carta de Ronquillo, Génova, 26-III-1649. Además de la conjura de Balbi, que había sido precedida dos años antes por la «mobba dei gentiluomini» destinada a poner freno a la admisión de nuevas inscripciones en las filas de la nobleza, siguió, en 1650, el complot anti-español protagonizado por Stefano Raggio y Ottaviano Sauli. Sobre estas cuestiones véanse las páginas que les dedica GRENDI, E.: I Balbi. Una famiglia genovese fra Spagna e Impero, Turín, 1997, pp. 196-202 y BITOsSI, C.: «'Mobbe' e congiure. Note sulla crisi política genovese di metà seicento" en Miscellanea Storica Ligure, XVIII, (1986), pp. 587-626. Sobre la conjura de Raggio son reveladoras las apreciaciones del embajador Diego de Laura, AGS, Estado, leg. 3605, Génova, 10-VII-1650

71 AGS, Estado, leg. 3607, Consulta del Consejo de Italia en torno a las pretensiones genovesas sobre Finale, Madrid, 18-VI-1654. En esta misma consulta se indica cómo el primer altercado de importancia por estas cuestiones se produjo el 22 de mayo de 1639 con el apresamiento por parte 
bernador a la sazón de dicho ducado, de recuperar los proyectos destinados a construir una dársena o puerto capaz de convertir Finale en una adecuada plataforma desde la que comunicar el Estado de Milán con el resto de los territorios de la Monarquía sin necesidad de tener que depender de Génova para el tránsito de soldados o el paso de mercancías ${ }^{72}$.

La reacción genovesa no se hizo esperar. A principios de 1654 el gobierno de la república procedía al apresamiento de un buen número de naves finalinas acusadas de llevar productos de contrabando y de evadir el pago de los dacios. Una medida semejante exacerbó los ánimos anti-genoveses en la Monarquía y parecía darle la razón a aquellos que, como Martínez de la Mata, denunciaban la ingratitud y la "amistad fingida" de los genoveses que, a cambio de sus préstamos y mediante la compra de feudos o el control de las principales rentas de la Monarquía, habían sido los causantes del total empobrecimiento del reino ${ }^{73}$. La necesidad de emanciparse de su tutela y la capacidad de que gozaba la corona para castigarles duramente en sus intereses animó a los ministros del rey a poner finalmente en práctica un elenco de medidas de represalia para cercenar

genovesa de una nave finalina. El pormenorizado informe del Consejo de Italia se remonta hasta el siglo XIV para estudiar la situación del marquesado. En este mismo legajo contamos con mucha información sobre las exigencias genovesas, de entre la que destacan los escritos de Raffaele della Torre, y sobre el proceso de negociación y conflicto en torno a este asunto. Al respecto, consúltese la respuesta ofrecida por el dux al secretario de la embajada española en Génova sobre estos derechos, Génova, 13-IX-1653. Se adjuntan también varios documentos relativos a los altercados sobre la distribución de la sal, Milán, 25-IX-1653. Véase asimismo, Archivio di Stato di Napoli (ASN), Segreterie dei Vicerè, leg. 175, Carta de Diego de Laura al virrey de Nápoles sobre las diferencias que pasan entre la república y Finale, Génova, 29-XII-1653.

72 Aunque las limitaciones geográficas de Finale hacían muy difícil convertirlo en un adecuado sustituto de Génova, por no hablar de las restricciones presupuestarias por las que pasaba la corona, la medida fue estudiada con detenimiento. El propio Martínez de la Mata, en un furibundo alegato contra los genoveses señalaba al respecto: «La fábrica y fundación del puerto del Finale, tan necesario al servicio de Vuestra Majestad, pues consiste en él la unión de los Estados y recíprocos auxilios de las armas de Vuestra Majestad y el Emperador fueron los mayores desvelos del señor Rey D. Felipe II...Esta obra de tan suma importancia al servicio de Vuestra Majestad, con astucias y negociaciones ha estorbado la república de Génova 54 años.» MARTíneZ DE LA MATA, F.: Memoriales y Discursos. Edición crítica a cargo de Gonzalo Anes, Madrid, 1971, p. 270.

73 Los memoriales de Martínez de la Mata recogen todos los prejuicios que, desde mediados del siglo XVI, se habían ido formulando sobre el carácter ambicioso, usurero y ruin de los genoveses y sobre sus artimañas para engañar a la Monarquía que «siendo la fuente de los tesoros del mundo la han dejado agotada genoveses y quieren dar a entender a todos que por ellos sustenta Vuestra Majestad su Monarquía prestándole dineros; no teniendo ellos más que lo que chupan a los vasallos y a la Real Hacienda." En MARTínez DE LA MATA, F.: Memoriales y dsicursos...cit., p. 269. Planteamientos que fueron retomados en un memorial de 1656 por Juan Bautita Cicardo que, en un detallado informe sobre los fraudes y los excesos cometidos por los genoveses, concluía afirmando: «ninguna conveniencia a España y a toda esta Monarquía se le sigue de su trato y amistad...como en su octavo discurso latísimamente lo manifiesta Francisco Martínez de la Mata.» ASG, Archivio Segreto, leg. 2450, Memorial de Juan Bautista Cicardo incluido en una carta remitida por Ansaldo Imperiale al serenísimo gobierno de Génova desde su embajada en Madrid, Madrid, 2-IX-1656.

Hispania, LXV/1, núm. 219 (2005) 115-152 
los constantes ultrajes de la república y limitar sus veleidades autonomistas. Ante la negativa de Génova a devolver los navíos confiscados, el marqués de Caracena publicó una ordenanza real por la que se procedía al embargo de todos los bienes y rentas de los genoveses en los territorios italianos de la Corona. La medida causó un enorme revuelo de manera especial en el reino de Nápoles pues, como señalaba con preocupación el virrey, conde de Castrillo, sería muy difícil distinguir a los genoveses de los naturales y se corría el riesgo de colapsar el comercio y dificultar el abasto del reino en un momento en el que se temía una posible invasión francesa ${ }^{74}$. Las enormes sumas procedentes de los bienes y rentas requisados reflejaban el arraigo de los genoveses en los reinos de la Monarquía ${ }^{75}$ pero lo indiscriminado de la ordenanza limitaba su efectividad pues afectaba en mayor medida a aquellos sectores más apegados a los intereses españoles y, en lugar de servir como escarmiento, acabó dándole alas a los grupos que apostaban por romper definitivamente los lazos con Madrid ${ }^{76}$.

"Il nome spagnolo comincia ad essere odiatissimo», señalaba un aviso enviado a Florencia desde Génova en el que se subrayaba el efecto indeseado logrado por el embargo al haber ayudado a unificar las energías de facciones hasta entonces enfrentadas. El hecho insólito de que incluso uno de los principales miembros del partido español, el duque de Tursi, hubiese llegado a ofrecer el servicio de sus escuadras de galeras en caso de que se produjese una ruptura

${ }^{74} \mathrm{La}$ aplicación del embargo sería muy complicada porque: «muchos, aunque tengan su origen de Génova han vivido allí muchos años con sus casas, familia y hacienda y adquirido naturaleza y privilegios legales que se les han observado añadiéndose a algunos la calidad de haber nacido en aquel reino y aún sus padres. Que el embargo les ha comprendido bienes muebles y raíces y sus rentas con que hoy se hallan sin alimentos para sustento de la vida humana y los hombres de negocios con débitos y letras que satisfacer y embargados en los bancos su dinero.» En esa misma carta, adjuntaba las protestas de personas muy cercanas a la Monarquía y con puestos en el Consejo Colateral como los Príncipes de Satriano, el de Chelamar y el marqués de Mari o de las principales familias de la facción proespañola como las casas de Doria y el marqués de los Balbases por lo que concluía: «el embargo ha sido ejecutado en tiempo tan poco a propósito que trae consigo muchas y graves consecuencias.» AGS, Estado, leg. 3607, Consulta del consejo de Estado sobre dos cartas del conde de Castrillo de 4 y 8 de mayo, Madrid, 30-VI-1654. La correspondencia de Castrillo abunda en estas cuestiones. Véase, en especial, ASN, Segreterie dei Vicerè, leg. 181, Carta de Castrillo a Caracena exigiéndole mayor precisión sobre los procedimientos y alcance del embargo, Nápoles, 2-V-1654 así como una carta personal al marqués de los Balbases mostrando su malestar por la medida, Nápoles, 5-V-1654.

75 En la actualidad estamos llevando a cabo, junto a Gaetano Sabatini, un estudio sobre la minuciosa relación de los bienes genoveses secuestrados en Nápoles en la que se precisa el nombre de los afectados, la calidad de los mismos, el dinero que poseían en los bancos, los feudos, animales, deudores, importe de las entradas, arrendamientos y rentas que controlaban en las 12 provincias del reino, AGS, Estado, leg. 3607, Relación de bienes de genoveses confiscados, Nápoles, julio 1654

76 Sobre el impacto causado por esta medida en la república véase, CASONI, F.: Annali della repubblica di Genova nel decimo sesto, Vol. VI, Génova, 1779-1800, p. 53. Al respecto consúltense la rica correspondencia mantenida por Paolo Vincenzo Spinola desde su legación en Madrid, ASG, Archivio Segreto, leg. 2448.

Hispania, LXV/1, núm. 219 (2005) 115-152 
militar con la Monarquía así parecía indicarlo ${ }^{77}$. A finales de mayo, el Gran Consejo, sin dar aún por cerrada la vía del diálogo con Madrid, adoptó una batería de disposiciones que parecía anunciar el definitivo comienzo de las hostilidades. Junto a los pertinentes preparativos militares, que debían financiarse con la creación de una nueva tasa y gracias a los elevados donativos ofrecidos por los particulares, se nombraron embajadores para recabar el apoyo de Roma, Francia, Inglaterra y Venecia ${ }^{78}$. Mientras Cromwell recibía al enviado genovés, Ugo Fieschi, con honores reales 79 , la corona francesa aprovechaba la ocasión para ofrecer una completa alianza a la república por la que se otorgaba la asistencia de 2.000 caballos y de 4.000 infantes y se comprometía a no firmar la paz con el monarca Católico hasta que no hubiesen sido restituidos todos los bienes confiscados ${ }^{80}$. Más inquietud provocó en Madrid la puesta en marcha de una nueva ley según la cual, todo aquel que firmase asientos u ofreciese cualquier tipo de préstamos a un príncipe extranjero sería condenado a un destierro de cinco años en Córcega. La medida ponía en entredicho la financiación de la futura campaña militar en el Milanesado y en los Países Bajos como indicaba el hecho de que Domingo Grillo hubiese suspendido sus pagos en Amberes. La única salida parecía estar, en opinión del conde de Peñaranda, en una escalada de la tensión mediante la confiscación de la plata que viniese consignada para los genoveses en los Galeones y en las Flotas que se esperaban y la ampliación

77 Sin que su propuesta fuese aceptada por el gobierno de la república que impidió la salida de sus galeras pues recelaba de que pudieran ponerse al servicio de España, ASF, Mediceo del Principato, Avissi di Genova, leg. 2860ª , Génova, 23-V-1654.

${ }^{78}$ A esta última se le ofrecía, siguiendo las recomendaciones de Bernardo Veneroso, una liga ofensiva y defensiva a favor de la estabilidad de Italia. Además se proponía la compra de 10 nuevas naves, de las que 4 deberían de ser de guerra, y una leva de 7.000 infantes, ASF, Mediceo del Principato, Avissi di Genova, leg. 2860ª , Resoluzione presse dal Gran Consiglio di Genova, 27-V-1654. Sobre el impacto con el que fue recibida la noticia del embargo de los bienes genoveses en los dominios italianos de la corona véase, AGS, Estado, leg. 3607, Carta del marqués de la Fuente en la que indica que en Venecia la medida se había interpretado como una ruptura del status quo y como una amenaza del rey sobre Italia. La liga de ambas repúblicas parecía inminente, Venecia, 20-VI-1654.

79 Situación que causó un altercado con Alonso de Cárdenas, embajador español en Londres al que, según indica Accinelli, Cromwell contestó con el siguiente alegato republicanista: «Inghilterra e Genova sono ambedue Repubbliche; così si vogliono onorare a vicenda; ambe sono sotto la protezione di San Giorgio», recogido por VITALE, V., La diplomazia genovese...cit., pp. 35-36.

80 BNM, Mss. 1443, «Proposizione dei ministri del Cristianesimo alla repubblica di Genova per far lega offensiva e difensivas incluida en una carta enviada a la república por Louis Delomenie, Reims, 11-VI-1654. Se solicitaba también la posibilidad de realizar un asiento de seis galeras en Génova en igualdad de condiciones que las estipuladas por el duque de Tursi con España y se ofrecía una mediación ante el Papa para que reconociese los honores pedidos por la república, así como ante la Sublime Puerta y las Provincias Unidas para facilitar la entrada de los hombres de negocios genoveses en el Levante y en las Indias Orientales. Por último, se permitía la libre extracción de granos del reino y se otorgaban nuevas facilidades a los cónsules de la república para reforzar sus intercambios en Francia

Hispania, LXV/1, núm. 219 (2005) 115-152 
del embargo de sus bienes al reino de Castilla ${ }^{81}$. Las nuevas amenazas no tardaron en surtir efecto y el gobierno de la república volvió a recurrir al camino de la negociación a través del envío de una embajada extraordinaria a Madrid encabezada por Gio Francesco Sauli ${ }^{82}$. Las tratativas fueron complicadas y estuvieron a punto de romperse en varias ocasiones. A finales de año, se llegaba a un acuerdo por el que, a cambio de la devolución de las naves finalinas se restituían los bienes confiscados a los genoveses sin que se diese una solución satisfactoria a los problemas que habían conducido a la crisis. La mala situación de la hacienda hacía aconsejable, según advertía el duque de Sanlúcar, «no añadir una nueva guerra a las que hoy afligen a esta Monarquía», por muy lesiva que esta tregua fuese para el crédito y el decoro de la corona, ante la imposibilidad de encontrar fuentes alternativas de crédito ${ }^{83}$.

Por su parte, Génova recelaba cada vez más de un posible fortalecimiento de la posición francesa en el Mediterráneo occidental visto que, a pesar de las buenas palabras y de las promesas incumplidas, los corsarios al servicio de Luis XIV mostraban una agresividad que superaba con creces a la de sus contrincantes finalinos. $\mathrm{El}$ acuerdo con Madrid permitía poner finalmente en funcionamiento uno de los más ambicioso proyectos de los navalistas: el convoy de comercio destinado a proteger el envío de las partidas de plata procedentes de Cádiz y cuya primera expedición tuvo lugar en 1655. Poco antes de que se resolviese el contencioso de Finale, Génova había contribuido incluso a frenar el ataque francés contra el reino de Nápoles. En plena crisis, la república dio su conformidad al duque de Tursi para que pudiese volver a ponerse al servicio del monarca Católico, medida que

81 En la consulta del Consejo de Estado en la que se analizó esta cuestión, tan sólo Don Melchor de Borja mostró sus reticencias ante la aplicación de estas nuevas medidas de fuerza pues «sería faltar a la fe pública y en grave perjuicio de todo el comercio» AGS, Estado, leg. 3607, Consulta del Consejo de Estado, Madrid, 12-VII-1654.

82 El 25 de junio de 1654 la república emitió las instrucciones para Giovanni Francesco Sauli. Ciasca recoge la extensa relación de su embajada, con fecha de 6 de octubre de 1655, en la que se observan las dificultades para alcanzar un acuerdo y la postura de los principales ministros españoles sobre este asunto. CIASCA, R., Istruzioni e relazioni degli ambasciatori...cit., Vol. III (1636-1655), Roma, 1955, pp. 289-330. El Consejo de Estado aprobó finalmente el compromiso en diciembre de 1654, AGS, Estado, leg. 3607, Consulta del Consejo de Estado, Madrid, 12-XII-1654.

83 Aún así, proponía que se estuviese preparado para una nueva contingencia por lo que pedía que «con todo secreto se le envíen a Vuestra Majestad relación de las rentas que tienen todos los de la nación genovesa en estos reinos de Castilla, mandando Vuestra Majestad no se permita ni traspaso, ni venta, ni enajenación por ningún título que sea.» Se trataba de impedir una salida en masa de los genoveses de los dominios del rey y de buscar fuentes alternativas de crédito para evitar, en el futuro, la completa dependencia con respecto a sus asientos: "Y porque el mayor daño que nos pueden hacer consiste en la falta que nos harán para los asientos y remisiones de dineros a los estados de Flandes y de Milán suplicaría el duque a Vuestra Majestad se procurase esto suplir viendo si habrá flamencos, holandeses o ingleses con quien poder tratar.» AGS, Estado, leg. 3607, Voto del duque de Sanlúcar en la Consulta del Consejo de Estado, Madrid, 12-XI-1654.

Hispania, LXV/1, núm. 219 (2005) 115-152 
permitió frustrar el desembarco francés en Castelmare a finales de $1654^{84}$. Pero no era tan sólo el temor a Francia lo que había empujado a favor de un restablecimiento de relaciones con Madrid. Los problemas de desabastecimiento provocados por el eventual cierre de unos mercados vitales para el buen funcionamiento del emporio genovés y las quejas de los particulares, en especial de la comunidad genovesa en Castilla, vinieron a sumarse, a mediados de 1656, al estallido de una mortífera epidemia de peste. Las consecuencias del contagio, que no cesó hasta finales de 1657 y que se cobró la vida de unas 50.000 personas, fueron catastróficas para la estabilidad social y, como apunta Bitossi, acabaron por dar al traste con la ambiciosa política autonomista de los republiquistas ${ }^{85}$.

\section{LA AMENAZA DE FRANCIA Y EL REDIMENSIONAMIENTO DE LAS RELACIO- NES HISPANO-GENOVESAS}

El acuerdo alcanzado entre Francia e Inglaterra en 1657 y los sucesivos éxitos militares de los coaligados a costa de la Monarquía Hispánica eran vistos con una creciente desconfianza desde Génova. Los informes secretos que llegaban a la república no podían ser menos tranquilizadores. A un esperado ataque naval contra alguna plaza estratégica en la costa ligur se sumaba la posible colaboración francesa con el ambicioso duque de Módena o una renovación de sus tradicionales acuerdos con Saboya ${ }^{86}$. La firma de la paz de los Pirineos en 1659 fue acogida con

${ }^{84}$ AGS, Estado, leg. 3608, Consulta del Consejo de Estado con varias cartas del duque de Tursi en las que informa de la derrota francesa frente a Torre Annunziata en el reino de Nápoles, Madrid, 16-XII-1654.

${ }^{85}$ En palabras de Bitossi: «la peste rappresentò una sorta di spartiacque, e una pietra tombale su una stagione politica vivacissima.» En BITossı, C.: «L'Antico Regime genovese...cit., pp. 458459. A pesar de que muchos se refugiaron en sus residencias extramuros, la epidemia se cebó también con el restringido grupo dirigente que llegó a perder unas 300 personas lo que haría necesario facilitar las nuevas adscripciones. Peor fue su efecto en los grupos populares y se reactivó el temor ante un posible estallido revolucionario como indicaba el secretario de la embajada española, Diego de Laura: «Y si estos accidentes durasen podría temerse alguna sublevación del pueblo instigado del hambre a que no ayudaría poco el odio que tienen a la nobleza, la cual teme hoy más esto que el mismo mal.» AGS, Estado, leg. 3608, Carta de Diego de Laura, Génova, 8-X-1656. Las cifras sobre la mortalidad causada por la peste las ofrece PRESOTTO, D.: «Genova, 1656-1657. Cronache di una pestilenza", Atti della Società Ligure di Storia Patria, V, (1965), pp. 402-403.

86 ASG, Secretorum, 1575, Informe de un cardenal, del que no se dice el nombre, sobre los preparativos navales franceses en Tolón que hacen temer por la seguridad de Savona y del recelo con el que debían ser observados «gli inglesi desiderosi per opugnare l'interesi della religione di prender un posto in Italia.» Génova, 4-XII-1657. Otro papel anónimo de un «ministro» donde se señala que: «qua si discorre che $\mathrm{i}$ francesi possino avere qualche pensiero poco onesto sopra codesto stato...il duca di Modena è principe avido di gloria e di acquistar terreno i francesi lo seconderanno...quei rispetti che mossero i francesi l'anno del 25 ad unirsi con Savoia sono e saranno sempre i medesimi per l'avvenire.» Génova, 21-XI-1657. Estos escritos no son más que una pequeña prueba del gran número de informes sobre estas amenazas.

Hispania, LXV/1, núm. 219 (2005) 115-152 
alivio en Génova que se apresuró a solicitar al monarca Católico la inclusión de la república en el tratado en calidad de aliada de la corona en una demostración de buena voluntad que parecía dar por zanjados los anteriores malentendidos ${ }^{87}$.

Ahora bien, el restablecimiento de las relaciones con Madrid se sustentaba sobre bases bien distintas a las que habían dado origen a la anterior simbiosis hispano-genovesa. Aunque los intercambios mercantiles con los territorios bajo la jurisdicción del monarca Católico seguían ocupando un posición preponderante, no ocurría lo mismo con el mercado financiero. Los problemas de la hacienda castellana sumados al escaso respeto hacia los bienes de los particulares acabaron por provocar la salida de los capitales genoveses. La Monarquía siguió recurriendo a la puesta en práctica de embargos parciales para solventar todo nuevo choque con la república o para hacer frente a situaciones de emergencia. En 1660, 1668 y, de nuevo, en 1679, en respuesta a la captura de algunas naves finalinas, se decomisaron parte de los efectos que los genoveses tenían depositados en la deuda pública del ducado de Milán y se realizaron todo tipo de agravios contra sus intereses ${ }^{88}$. Otro tanto ocurrió en el reino de Nápoles donde, para hacer frente a la rebelión de Mesina, el marqués de Astorga había requisado 300.000 escudos de particulares genoveses ${ }^{89}$. En un detallado informe elaborado por Juan Carlos de Bazán, que actuó como embajador en Génova entre 1684 y 1693, se acusaba a este tipo de acciones de ser las causantes de la pérdida del crédito de la corona y de romper el vínculo de interés que era el único que: «los conservaba unidos en su amor y respeto hasta que, habiéndose comenzado a practicar los medios de la represalia en diferentes tiempos y ocasiones contra los pactos expresos de sus contratos, comenzaron algunos a vender sus montes y otros a hacer sus nuevos empleos en Francia, Polonia, Venecia y Roma y ahora últimamente en el Imperio» ${ }^{90}$.

${ }_{87}$ AGS, Estado, leg. 3609, Consulta del Consejo de Estado sobre la solicitud del residente genovés en Madrid para que, en el marco del artículo 122 del tratado de los Pirineos, el rey Católico declarase a la república de Génova como su aliada, Madrid, 8-IV-1660.

88 AGS, Estado, leg. 3641, Consulta del Consejo de Estado sobre el secuestro que, con motivo del apresamiento de una barca en Finale, llevó a cabo el conde de Fuensaldaña y sobre los efectos que tienen los genoveses en Milán, Madrid, 13-IV-1660. AGS, Estado, leg. 3612, Consulta del Consejo de Estado sobre el secuestro de bienes de genoveses como represalia por el apresamiento de dos naves finalinas «sin pasar a represalias generales», Madrid, 31-XII-1668. Sobre las tratativas llevadas a cabo por el enviado extraordinario en la Corte de Madrid, Giovanni Andrea Spinola, para resolver la disputa provocada por el embargo de bienes de genoveses en Milán dictado por el conde de Melgar, véase, CIASCA, R.: Istruzioni e relazioni...cit., Vol. V, p. 3 y ss.

89 AGS, Estado., leg. 3620, Consulta del Consejo de Estado sobre un informe del Consejo de Italia en torno a la retención en Nápoles de haciendas de genoveses. El consejo reconoce que se deben devolver los bienes incautados por Astorga pero no así los requerimientos de annatas hechos por el marqués del Carpio a forasteros y ausentes para acuñar nueva moneda, Madrid, 12-X-1684.

90 Situación que había permitido al Emperador disponer de dinero para hacer la guerra y, proseguía el informe: «por el contrario, esta desconfianza y mala correspondencia ha causado que abriendo el conde de Fuensaldaña nuevos montes y ofreciendo toda la seguridad y ventaja no se hallase persona que

Hispania, LXV/1, núm. 219 (2005) 115-152 
Pero si los genoveses no parecían estar en disposición de ejercer su anterior función de socios capitalistas del conjunto, la Monarquía Hispánica tampoco se mostraba capacitada para salir en defensa de la república como había hecho hasta el momento. El fracasado intento por recuperar Portugal ${ }^{91}$ y la patente debilidad militar mostrada en el frente flamenco con motivo de la guerra de Devolución constituían la mejor prueba de que el monarca Católico no podía ostentar la función de "protector de la libertad de la república». Ante eșta situación, resulta comprensible que, a partir de 1672, no se aceptase a trámite la tradicional inclusión de dicho término en las cartas credenciales de los enviados diplomáticos españoles ${ }^{92}$. En efecto, con motivo de la nueva invasión de Génova por parte del duque de Saboya ese mismo año, y frente a la enérgica actitud que había mostrado en 1625 , la Monarquía se vio obligada a adoptar una posición de completa pasividad y tuvo que ver con desagrado cómo era el mediador

quisiese emplear la menor partida que es un gran inconveniente para las necesidades públicas.» AGS, Estado, leg. 3636, Relación que hace Don Juan Carlos Bazán del tiempo que estuvo en Génova entre el 20-II-1684 y el 1-VII-1693. Los trabajos de Felloni corroboran esta retirada del crédito genovés de los distintos territorios de la Monarquía Hispánica, FELLONI, G.: Gli investimenti finanziari genovesi in Europa tra il Seicento e la Restaurazione, Milán, 1971. Por su parte, Carmen Sanz nos ofrece datos contundentes sobre la evolución experimentada por el capital genovés en sus tratos con la Monarquía Hispánica. En los asientos realizados entre 1666 y 1679, los genoveses pasan a ocupar la tercera posición entre los proveedores de fondos detrás de españoles y portugueses. Tan sólo los préstamos de las casas Piquenotti y Crota les mantienen en segundo lugar en las provisiones en plata. Entre 1680 y 1700 los genoveses acaban ocupando un papel residual y limitan su presencia al $8 \%$ del total de los préstamos, SANZ AYÁn, C.: Los banqueros de Carlos II...cit., pp. 247-248 y 296.

91 Durante la guerra de Portugal la república de Génova había contribuido a romper el bloqueo de la costa lusa, AGS, Estado, leg. 3609, Consulta del Consejo de Estado sobre una carta del secretario de la embajada, Diego de Laura, en torno a la provisión que los genoveses hacen de trigo siciliano a cambio de azúcar: «no sólo se debe sentir que socorran al rebelde sino que lo hagan con granos del dominio de Vuestra Majestad, siendo cierto que todo lo que va de allí es traído de Sicilia por medio de los genoveses que residen en aquel reino." La medida que se adopta en esta ocasión es la de solicitar a los corsarios mallorquines que se encargasen de agredir dichas naves, Madrid, 17-V1662. Las amenazas no surtieron efecto y los genoveses siguieron abasteciendo a los portugueses de trigo, AGS, Estado, Consulta del Consejo de Estado sobre una carta de Laura sobre esta materia. Se resuelve que: «se dé a entender a la república que si continúa en socorrer al rebelde les prohibirá Vuestra Majestad el comercio en todos los puertos de su Monarquía y aunque conoce el Consejo cuánta ingratitud sea de la república el esquivar la conmemoración de lo que debe a la Real protección de Vuestra Majestad y sus gloriosos progenitores cuando es tan notorio que por ella goza su libertad y el no haber sido saqueada del ejército de Saboya el año de 1625.» Madrid, 16-XI-1664.

92 AGS, Estado, leg. 3636, Consulta del Consejo de Estado sobre una carta de enviado Antonio Mendoza, marqués de Villagarcía, sobre el uso de la palabra protección en sus credenciales, Madrid, 22-XI-1672; en el mismo legajo, Consulta del Consulta del Consejo sobre los reparos puestos a Coloma porque dicha palabra no se correspondía con una república libre y totalmente independiente, Madrid, 25-VIII-1677. No obstante, en 1684, la república volvería a aceptar el término protección a lo que, en palabras del nuevo embajador Juan Carlos Bazán, «ayudó mucho la condición del tiempo hallándose la república amenazada de las armas de Francia.» Extracto incluido en la ya citada relación de su embajada que se encuentra en este mismo legajo.

Hispania, LXV/1, núm. 219 (2005) 115-152 
enviado por Luis XIV, el conde de Gaumont, el que restablecía la situación ${ }^{93}$. El ataque conjunto franco-británico contra las Provincias Unidas suponía una agresión paralela contra la otra gran aliada de la corona y constituía la mejor prueba de que Francia parecía dispuesta a liberarse definitivamente del papel mediador jugado hasta entonces por dichas repúblicas y a romper con la tutela ejercida por sus hombres de negocios en sus mercados. Posición del todo opuesta a la mantenida por Madrid que, como se observa en una elocuente carta remitida por el embajador español en La Haya, Francisco Manuel de Lira, a su homólogo en Génova, marqués de Villagarcía, mostraba su temor ante la crítica situación por la que atravesaban unas repúblicas de las que parecía depender la conservación de la Monarquía: "Parece que estamos -afirmaba en 1673 - en la era climatérica de las repúblicas según el ajuste de la de Génova en que no tenemos que sentir tanto sus pocas ventajas como la subordinación con que queda a la Francia para adelante que es pie que puede arrastrarnos grandes inconvenientes en cuyo mal presagio no peligra poco esta república con tanto riesgo de nuestros intereses» ${ }^{94}$.

La debilidad militar española para hacer frente al desafío de Francia explica la escasa colaboración naval genovesa a la hora de acudir con sus galeras a sofocar el levantamiento de Mesina ${ }^{95}$ y su reticencia a entrar en la liga defensiva propuesta por Madrid al resto de las potencias italianas en contra de la pretensiones france-

93 Y ello a pesar de la ayuda militar prestada por Francia a Turín durante la contienda. Las tropas genovesas se mostraron capaces de repeler el ataque de Carlos Manuel II de Saboya con mayor efectividad de la inicialmente prevista, a lo que contribuyó el rotundo fracaso de la conjura de Raffaele della Torre, sobrino del famoso republiquista. Al respecto véase, CACCIABUE, F.: «Per una biografia di Raffaele della Torre», Miscellanea Storia Ligure, XVIII, 2, (1986), pp. 627-639. Las presiones del grupo filo-francés que se estaba formando en la república impidieron la tramitación del posible sostén que podría haber remitido desde Milán el duque de Osuna. Las quejas expresadas por el Almirante de Castilla en el Consejo de Estado por la dejación de responsabilidades de la Monarquía son expresivas del vigor que estaba tomando en la Monarquía el grupo belicista que implicaría a España en la guerra de Holanda el año siguiente. AGS, Estado, leg. 3613, Consulta del Consejo de Estado sobre una carta del marqués de Villagarcía en torno a las pretensiones francesas de, a cambio de su papel mediador en el conflicto con Saboya, establecer una escuadra de galeras en Génova, Madrid, 6-XII-1672. Sobre las distintas posturas en la Corte ante la invasión francesa de las Provincias Unidas véase, Herrero SÁNCHeZ, M.: «La Monarquía Hispánica y el Tratado de La Haya de 1673» en Lechner, J. y Boer, H. (eds.) España y Holanda. Ponencias leídas durante el quinto coloquio bispano bolandés de bistoriadores, Diálogos Hispánicos n¹6, Ámsterdam, 1995, pp. 103-118.

${ }_{94}^{4}$ AGS, Estado, Embajada de España en La Haya, leg. 8652, Carta de Lira al marqués de Villagarcía, La Haya, 10-IV-1673.

95 Es cierto que, en 1674, el marqués de Villagarcía había logrado que la república enviase 5 galeras a Mesina pero su colaboración no fue a más, a pesar de los intereses genoveses en el mercado de la seda siciliana y, desde luego, no era comparable al consistente apoyo naval ofrecido por las Provincias Unidas. AGS, Estado, Embajada de España en La Haya, leg. 8652, Carta de Lira a Villagarcía felicitándole por haber obtenido el envío de varias galeras a Mesina, La Haya, 27-VIII-1674.

Hispania, LXV/1, núm. 219 (2005) 115-152 
sas en la península ${ }^{96}$. La neutralidad, sin embargo, no era suficiente para frenar las crecientes exigencias de Luis XIV que, deseoso de lograr nuevas concesiones de los que el marqués de Seignelay denominaba «los holandeses de Italia», procedió a bombardear San Remo y Sampierdarena en $1678^{97}$ como preámbulo de una ofensiva diplomática y militar destinada a romper los lazos que ligaban todavía a la república con el monarca Católico. En 1682, Versalles enviaba su primer residente permanente a Génova, Saint-Olon, por lo que se rompía el monopolio ejercido hasta el momento por el embajador español y su capacidad para estar al tanto, de manera exclusiva, de los complejos mecanismos de la toma de decisiones del gobierno genovés98. La negativa de la república a aceptar el ultimátum ofrecido por Saint-Olon se concretó en un bombardeo masivo de la ciudad por parte de la flota francesa en mayo de $1684^{99}$. El apoyo armado enviado desde Milán, aunque limitado por exigencias de la misma república, permitió mantener el orden en el interior de la ciudad y era una prueba palmaria del tradicional compromiso de Madrid en defensa de la libertad de Géno$\mathrm{va}^{100}$. No obstante, el fracaso español en su intento de incluir a la república en la tregua de Ratisbona ${ }^{101}$ y los preparativos de una campaña militar por tierra, que podría suponer la completa anexión de Génova por parte de Francia movieron al gobierno a alcanzar un acuerdo de paz con Versalles. Por dicho trata-

\footnotetext{
96 AGS, Estado, leg. 3616, Respuesta de la república a Manuel Coloma por la que Génova declina participar en cualquier tipo de liga en Italia pues podría poner en peligro la estabilidad. Aún así muestran su total apoyo a la Monarquía, Génova, 10-V-1678.

97 AGS, Estado, leg. 3616, Carta de Manuel Coloma sobre el bombardeo francés de San Remo, Génova, 3-IX-1678.

98 Como señalaba Juan Carlos de Bazán en su ya mencionada relación, la llegada de SaintOlon obligó a la república a prohibir por completo las visitas de cualquier ministro extranjero a la nobleza lo que dificultaba las negociaciones diplomáticas. La única manera de estar al tanto de los pormenores políticos consistía en acudir a «los festines o conversaciones de las Damas...porque además de ser muy honesta y decorosa en su casa se comunica con toda la nobleza y ministros de aquel gobierno y ellas tienen mucha autoridad en él y mucha parte en el secreto.» De todos modos, el mayor problema que sufría el embajador español era la falta de provisiones remitidas desde Madrid lo que le impedía efectuar sobornos y ganar voluntades de igual manera que lo hacía el enviado francés, AGS, Estado, leg. 3636, Relación de la embajada de Bazán entre 1684 y 1693 fol. 637.

$99 \mathrm{Al}$ respecto véase BITOSSI, C.: «Il picolo sempre succombe al grande: la Repubblica di Genova tra Francia e Spagna, 1684-1685» en Il bombardamento di Genova nel 1684. Atti della Giornata di studio nel terzo centenario, Génova, 1988, págs. 39-69 y BOTTARO PALUMBO, M.G.: «La crisi dei rapporti tra Genova e la Francia negli anni Ottanta del secolo XVII» en Belvederi, R. (ed.), Rapporti Genova-Mediterraneo-Atalantico nell'età moderna, Génova, 1990, pp. 137-176.

${ }_{100}$ El embajador Bazán señala las dificultades que tuvo para que el Conselleto votase la admisión de un contingente militar procedente del ducado de Milán debido al recelo mostrado por «los parciales o temerosos de Francia», AGS, Estado, leg. 3636, Memorial de Bazán. En AGS, Estado, leg. 3620, Carta del dux a Madrid agradeciendo «los socorros que se ha servido mandar ponderando la puntualidad con que los ministros de Italia han obrado en esta ocasión.» Génova, 7-VII-1684.

${ }_{101}$ Los pormenores de la fracasada negociación española para permitir la inclusión de Génova, en calidad de aliada, en la tregua de Ratisbona se pueden consultar en AGS, Estado, leg. 3620.
}

Hispania, LXV/1, núm. 219 (2005) 115-152 
do, se procedía al desarme de la flota de galeras y se efectuaba un sinfín de concesiones de las que la petición de disculpas por parte del dux en la Corte francesa constituía la prueba más fehaciente de la sumisión de la república con respecto a Francia ${ }^{102}$. Un acto de sometimiento que, como señalaba con acierto el enviado genovés en Madrid, Gio Andrea Spinola, permitía a Luis XIV sentenciar el final de la hegemonía española en Italia al «screditare presso gli amici ed alleati suoi la corona Cattolica dandola a conoscere o per impotente o per non curante di assisterli e sostenerli» ${ }^{103}$.

La progresiva debilidad de los partidarios de la alianza española en la república, en especial tras el nuevo embargo parcial de bienes genoveses en Milán en 1685 , no se tradujo en la formulación de un grupo definido de defensores de la causa francesa pues, como señalaba el embajador español: «entre la injuria de los franceses y el despojo de los españoles es dificultoso discernir de quién se deben dar por más agraviados» ${ }^{104}$. El triunfo de la moda francesa y el atractivo que despertaban sus mercados no fueron suficientes para borrar la memoria del bombardeo y las constantes insinuaciones sobre una posible anexión de la república, por lo que los dirigentes genoveses se inclinaron por adoptar una posición de neutralidad pasiva de la que extrajeron algunos importantes beneficios ${ }^{105}$.

El permanente estado de guerra en Europa, agravado por el enfrentamiento naval entre las potencias marítimas y Francia, permitió un extraordinario florecimiento de la marina mercante genovesa y explica, en parte, el abandono del rígido sistema del convoy instituido en 1655 106: Las Provincias Unidas e Ingla-

102 AGS, Estado, leg. 3621, Carta de Bazán sobre los preparativos para la salida del dux y 4 senadores hacia París. Muestra su postura crítica hacia una paz que no sólo iba en «injusto sacrifício de la seguridad, honor y reputación de esta república» sino que no ofrecía ninguna estabilidad pues «tal es el fundamento de su tratado que en cada paso temen un nuevo peligro», Génova, 15-III-1685.

103 Relación de Gio Andrea Doria de su embajada en Madrid entre 1681 y 1688, CIASCA, R. Istruzioni e relazioni...cit., Vol. V, p. 114.

${ }^{104}$ AGS, Estado, leg. 3621, Carta de Bazán sobre la jornada del dux a Francia, Génova, 2-VI1685. En su relación sobre su embajada, Bazán insistía en lo perjudicial de las represalias para los intereses de la Monarquía porque «todas estas rentas pertenecen a la nobleza que es del partido de Su Majestad y que aquel partido de los parciales de Francia no tiene en ellas interés ninguno, de que se sigue que todo el daño lo padecen los que han servido a Vuestra Majestad y quedan con toda inmunidad los que se le han opuesto, de manera que les dan impulsos de vender sus rentas o de dejar el partido.» AGS, Estado, leg. 3636, Relación de Bazán, fol. 639.

105 De nuevo es conveniente reproducir las pertinentes opiniones de Bazán cuando indicaba: «Debo remover su real ánimo de las voces inadvertidas y vulgares de que aquella república es francesa por genio o por conveniencia porque estas las vierten muchos sólo con la apariencia de los trajes y las costumbres y otras modas que ha introducido la Francia siendo esto pecado de casi toda la Europa y sobre algunas observaciones de respeto y atención que conservan con la Francia sin penetrar las causas, ni distinguir las pasiones del amor, del miedo o del deseo de la quietud pública...La república en cuerpo de gobierno profesa con particular estudio la neutralidad y a ella tira todas sus líneas y designios.» Ibíd., fol 638.

$106 \mathrm{Al}$ respecto véase BRAUDEL, F.: En torno al Mediterráneo, Barcelona, 1997 ( $1^{\text {a }}$ ed. en francés de 1996), p. 423. 
terra exigieron a la Monarquía Hispánica la aplicación de una batería de medidas de control y castigo para evitar lo que consideraban una práctica abusiva por parte de los mercaderes genoveses: la canalización de los productos franceses de contrabando bajo el pabellón neutral de la república, quebrantando el embargo general contra la entrada de dichos productos en los puertos españoles. Desde Madrid se instruyeron órdenes a los veedores para actuar con mayor rigor contra estos excesos y se llegó a realizar una expedición naval de amenaza frente a las costas genovesas en $1692^{107}$. La república salió en defensa de sus hombres de negocios mediante el envío de una embajada extraordinaria y a través de la difusión de numerosos memoriales remitidos a los cónsules de su nación en los principales puertos de la Monarquía ${ }^{108}$. El imponente aumento del número de naves genovesas se debía, según ellos, a la paralización de las actividades de sus contrincantes comerciales y no a la canalización de los productos franceses. Las acusaciones anglo-holandesas tenían por objeto impedir la llegada de las mercancías necesarias para el buen funcionamiento de la Carrera de Indias e impulsar el tráfico directo con las colonias españolas desde sus puertos. Una práctica a la que habían recurrido los propios genoveses con anterioridad enviando sus manufacturas a Ámsterdam para evitar el pago de los indultos en Cádiz y a la que, según señalaban, se habían visto forzados por no gozar de los exenciones y privilegios que, gracias a los ventajosos tratados de comercio, tenían las Provincias Unidas e Inglaterra en los puertos españoles ${ }^{109}$.

Las ventajas que la república había extraído de la guerra de la Liga de Ausburgo estaban lejos de ser duraderas y reposaban en un absoluto sometimiento a la voluntad del rey de Francia que, frente a lo que había ocurrido con el mo-

107 ASG, Archivio Segreto, leg. 2657, Carta del cónsul genovés en Cádiz, Giacommo Pavia, sobre las quejas del rey y la exigencia del gobierno español de limitar el tráfiço genovés con España a 3 naves anuales y de mostrar un certificado con el origen de las mercancías. Cádiz, 23-XII-1691. La presión de los veedores de contrabando españoles fue especialmente virulenta en Cádiz. Al respecto véanse los múltiples altercados producidos en 1689 y recogidos en AGS, Estado, leg. 3623. Consúltese también BITOSSI, C.: «L'antico regime genovese....cit. pp. 467-468.

${ }^{108}$ La relación de Francesco de Mari, enviado extraordinario a la corte del rey Católico en 1693 , la encontramos en CIASCA, R., Istruzioni e relazioni...cit., pp. 233-250. Véase también ASG, Archivio Segreto, leg. 2657, Memorial remitido por el cónsul genovés en Cádiz al rey sobre las causas del auge del comercio genovés, incluido en la carta del cónsul de Cádiz, 23-XII-1691.

109 Ya en 1687 Bazán advertía sobre el hecho de que los comerciantes de la república parecían optar por dejar de enviar sus ropas a los Galeones pues sus correspondientes les indicaban cómo los puertos de las Indias estaban saturados de las mercancías que enviaban franceses, ingleses y holandeses directamente y que les sería más útil navegar ellos también directamente o través de puertos ingleses y holandeses que pagar todos los derechos, indultos y demás opresiones que se hacen en Cádiz. AGS, Estado, leg. 3622, Consulta del Consejo de Estado sobre una carta de Bazán, Madrid, 4-2-1687. Más contundente era la solicitud del cónsul genovés en Cádiz que solicitaba al rey «la necessità che abbiamo di quelle franchigie et essenzioni che godono le nazioni del Norte» para comerciar en dicha plaza, ASG, Archivio Segreto, leg. 2657, Carta del cónsul genovés en Cádiz, Cádiz, 1-III-1693.

Hispania, LXV/1, núm. 219 (2005) 115-152 
narca Católico, no parecía contentarse con su papel de protector de la república. El memorial redactado por el embajador francés en Génova sobre los medios más convenientes para conquistar la república ${ }^{110}$ y la publicación de un buen número de escritos en los que se subrayaban las prerrogativas del rey sobre el dominio supremo de Génova ${ }^{111}$ venían a mostrar los peligros que entrañaba la nueva situación de aislamiento internacional. Las garantías arrancadas a la república tras el bombardeo de 1684 habían permitido a los franceses adquirir idénticos derechos a los reservados hasta el momento a la Monarquía Hispánica: uso de sus servicios navales; facilidades para los navíos y comerciantes franceses en el puerto de Génova y acceso a sus suculentos recursos financieros. Para una Francia en permanente conflicto armado con el resto de las potencias europeas y acosada por los sucesivos embargos y por el cierre de algunos de sus mercados más estratégicos la neutralidad forzosa de Génova le garantizaba una adecuada distribución de sus productos y permitía canalizar la entrada de numerario y de determinados materiales fundamentales para sostener su esfuerzo militar.

A pesar de todo, el peso de la república para el buen funcionamiento de la monarquía francesa estaba lejos de representar lo que había supuesto para el sistema imperial hispánico. Al igual que le ocurría a Inglaterra con respecto a las Provincias Unidas, Francia disfrutaba de la suficiente autonomía como para no depender de modo exclusivo de los servicios y de los recursos que podía proporcionarle Génova por muy valiosos que estos fueran. El papel protagonista ejercido a lo largo de los siglos XVI y XVII por las repúblicas mercantiles y su capacidad para ejercer una acción determinante en el equilibrio de fuerzas en el continente se desdibujaría a partir de la Guerra de Sucesión española. La autonomía con respecto a Madrid, por la que tanto habían abogado los republiquistas, lejos de permitir el retorno a una idealizada época dorada, había supuesto un completo desplazamiento de la república y una considerable reducción de las posibilidades de promoción y negocios para sus elites.

${ }^{110}$ BNM, Mss. 11021, Reflexiones hechas al rey de Francia por su embajador en Génova por los años de 1690 sobre el estado de las cosas de aquella república y sobre los medios que juzgaba convenientes para conquistarla.

111 AGS, Estado, leg. 3621, Resumen realizado por Juan Angulo sobre el escrito del procurador de Metz en el que se señala que Génova formaba parte de Francia por cesión de Carlos VI, Madrid, 25-V-1685. No olvidemos que, en está época, Francia estaba embarcada en la política de reuniones que le había permitido, gracias a la recuperación de derechos, incorporar ciudades libres como Estrasburgo e importantes enclaves en los Países Bajos sin necesidad de recurrir al uso de las armas. 